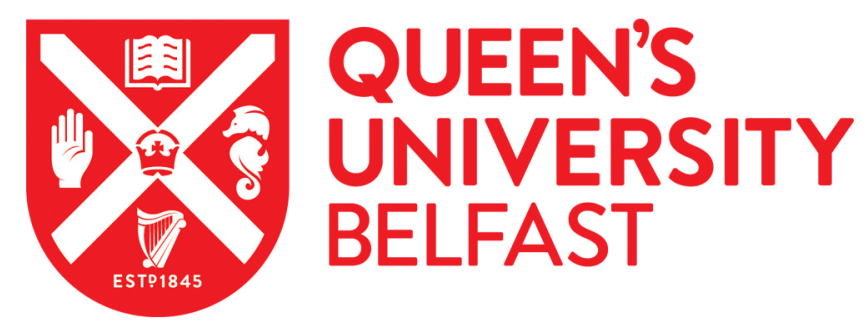

\title{
The phenomenal forms of political graffiti in Rome and Buenos Aires: a comparison based upon detailed descriptive analysis
}

Penn, R. (2019). The phenomenal forms of political graffiti in Rome and Buenos Aires: a comparison based upon detailed descriptive analysis. Visual Studies, 33(4), 313-325.

https://doi.org/10.1080/1472586X.2019.1590158

Published in:

Visual Studies

Document Version:

Peer reviewed version

Queen's University Belfast - Research Portal:

Link to publication record in Queen's University Belfast Research Portal

Publisher rights

Copyright 2019 Taylor and Francis. This work is made available online in accordance with the publisher's policies. Please refer to any applicable terms of use of the publisher.

\section{General rights}

Copyright for the publications made accessible via the Queen's University Belfast Research Portal is retained by the author(s) and / or other copyright owners and it is a condition of accessing these publications that users recognise and abide by the legal requirements associated with these rights.

Take down policy

The Research Portal is Queen's institutional repository that provides access to Queen's research output. Every effort has been made to ensure that content in the Research Portal does not infringe any person's rights, or applicable UK laws. If you discover content in the Research Portal that you believe breaches copyright or violates any law, please contact openaccess@qub.ac.uk. 


\title{
The Phenomenal Forms of Political Graffiti in
} Rome and Buenos Aires: a Comparison Based upon Detailed Descriptive Analysis.

\author{
Professor Roger Penn
}

School of Social Sciences, Education and Social Work

Queen's University

Belfast 


\section{Introduction}

This paper provides a comparison of political graffiti in Rome and Buenos Aires. The graffiti were photographed by the author in 2015 [Rome] and 2016 [Buenos Aires]. A central aspect of the analysis involves the desire and, indeed, the need to examine such visual data in detail. This stands in opposition to the traditional use of visual data within much orthodox sociology which involves the use of photographs to illustrate an associated written textual argument ${ }^{1}$. As such, the photographs themselves add very little to the overall argument. Indeed, more often than not they are redundant.

There has been a burgeoning interest in visual sociology over recent years. As recently as 1993 Jay (1993) lamented the lack of serious interest in the visual amongst sociologists. ${ }^{2}$ However, this has changed considerably since that time, as is shown in the great variety of themes researched through the use of visual data revealed in Margolis and Pauwel's seminal edited collection in 2011. There have also been a series of influential textbooks published that have supported the increased teaching of visual sociology in contemporary universities (see Rose, 2007 and Pink, 2012). Increasing interest in the visual is also evident in the growth of conferences such as those run by the International Visual Sociology Association and the International Sociology Association's Visual Sociology Group and also of the emergence of specialist journals such as Visual Studies, Visual Anthropology, Visual Anthropology Review, Visual Communication and the Journal of Visual Culture.

There has also been an explosion of interest in the topic of graffiti. Much of this literature focuses upon the visual aspects of graffiti. Such graffiti can take various forms including signature graffiti ['tags'] (see Castleman, 1982) and elaborate artistic images ['pieces'] (see Mininno, 2008) as well as street art (see Ganz, 2004, Mathieson, 2007 and Lewisohn, 2009). The most famous exponent of the latter is Banksy (see Banksy, 2005). Most books in this genre simply present colour

\footnotetext{
${ }^{1}$ See for instance Giddens, (2001) p380 and p383 and Kaplan and Li (2006) p22, p41 and p171.

2 There were notable exceptions of course such as Mead and Bateson (1942) and Harper (1987).
} 
photographs of graffiti themselves [see Marchi, 2007, Ruiz, 2008 and Palmer, 2008]. Others explain the connections between contemporary graffiti and counter-cultural youth movements [see Philipps, 1999; Mathieson, 2007; Naar, 2007; Peiter, 2009 and Snyder, 2009]. There has also been a concomitant increase in interest in historical forms of graffiti in both ancient Rome (see Lafrance, 2011 and Milnor, 2014) and medieval Britain (see Champion, 2015). Overall, there has been a growing multidisciplinary interest in graffiti as a valid area for social scientific research [see Miklavcic, 2008; Dickens, 2008; Valle \& Weiss, 2010; Pan, 2014; Hansen and Flynn, 2015; Vanderveen \& van Eijk, 2016 and Ross et al, 2017). Indeed, very recently two edited collections have cemented the legitimacy of the field amongst social science researchers (see Ross, 2016 and Avram \& Tsil, 2017).

The growing interest in graffiti as a topic for various styles of social scientific research has also extended to researching the political content of certain types of modern graffiti. Nwoye (1993) undertook a detailed content analysis of graffiti in university toilets. He found that 48 per cent of messages dealt with international/national political issues and a further 22 per cent focused more specifically on campus politics. $\mathrm{He}$ argued that such messages expressed the views of marginalised groups and stood in opposition to the dominant, official media discourse. Lennon (2014) analysed graffiti in Cairo during the period around the Arab Spring in 2011. His research probed how graffiti had been amended over time with additional imagery that modified its original meaning. This represented a dynamic, 'conversational' element to such polyphonic graffiti. Interestingly, some messages were in Arabic and others were in English suggesting that both writers and audiences for these conversations were complex in character and that the images themselves required local interpretation rooted in detailed contextual understandings.

The paper presents a detailed analysis of each of the two sets of photographs prior to a wider discussion of their phenomenological properties through a detailed and intensive process of descriptive coding. In this we are following the methodological precepts of Garfinkel (2007) in his admonition to sociologists that they should examine the detailed field properties of the phenomena under scrutiny rather than "rush to abstraction". The analysis is also inductive in that generalizations about the phenomenological field properties (see Garfinkel \& Livingston, 2003 and ten Have, 
2004) of such graffiti have been derived from a detailed examination of the photographs of the graffiti themselves.

The argument presented explicitly challenges the moralistic, external view of graffiti adopted by writers such as Sampson and Raudenbasch (1999 and 2004) and Sampson (2012) who see graffiti as an indicator or marker of something they term 'disorder' (see Vanderveen and van Eijk, 2015). This approach is inderpinned by a 'broken windows' view of the world which sees graffiti as an unambiguous sign of disorder and wider criminal activities. Such a viewpoint is explicitly rejected here. Graffiti is conceptualized in this paper as part of the ordering of the urban landscape in modern cities and the analysis is committed to exploring this in its finer details. Writers like Sampson and Raudenbasch simply 'see' one undifferentiated phenomenon - graffiti. It is very easy to label such phenomena as 'mindless' or 'antisocial'. However, the approach adopted in this paper suggests rather that graffiti are complex in their meanings, multi-faceted, multi-layered and sociologically interesting in their finer details. Indeed, they constitute a central element in the street code of the contemporary metropolitan city (see Anderson, 1999)

\section{The Fieldwork}

The photographs were collected in two stages. The first set was taken by the author in Rome in 2015. They were extensions of an earlier piece of visual sociology that compared Italian and English football (see Penn, 2002, 2004 and 2006a). Part of that research involved an analysis of graffiti in and around Italian football stadia (Penn, $2005,2006 \mathrm{~b}$ and 2008). This revealed a strong political tone to such graffiti and the pictures taken in central Rome in 2015 were designed to explore this phenomenon further. However, in the present paper they stand alone as examples of graffiti in the central urban zone of Rome. None of them were taken at or near the Stadio Olimpico - home to both AS Roma and SS Lazio. The ten photographs in Rome were selected from a wider set of photographs taken in the central zone of the city at the time. Their selection was both upon their intrinsic visual content and also to illustrate the nature of such graffiti. The photographs in central Buenos Aires were taken in early 2016 and were designed to provide a direct comparison with the earlier graffiti taken in central Rome Once again none of the photographs were taken near the several football stadia 
in Buenos Aires. They were also selected both for their visual qualities and to illustrate the characteristics of such Argentinian graffiti.

\section{The Photographs}

\section{Rome 2005}

\section{RED ZONE}

This graffiti was located in Monti in the centre of Rome close to the Colosseum, on an ivory coloured stucco wall. It comprises a left-wing political message written in red capitals with the Hammer and Sickle symbol immediately to the right of the written message 'RED ZONE'. Interestingly the message is written in English, but with an Italian style $z$. This suggests that the left were active in this area, which has a longstanding local tradition of cultural radicalism and Bohemian life styles (see Hewson, 2007).

\section{PAVOLINI EROE!}

This is another political message from the same street as the previous image, on the same type and colour of wall. The graffiti is in the form of a conversation between the far right and the far left. 'PAVOLINI EROE!' ['PAVOLINI THE HERO!'] has a Celtic Cross symbol immediately to the right. This has been crossed out, but not obliterated, in red and a Hammer and Sickle has been put up to the right of this. 'PAVOLINI EROE!' has also been crossed out in red, but remains clearly legible.

The message 'PAVOLINI EROE!' refers to Alessandro Pavolini, a prominent Fascist leader in the 1920s and 1930s, who was appointed Minister of Popular Culture by Mussolini in 1939 (see Pavone, 1991). After Mussolini's fall in 1943 Pavolini became a prime mover in the creation of the Brigate Nere [Black Brigades]. These were notorious under the Salò Republic for their brutal tactics against the Communist-led partisans in the last months of World War II (see Gagliani, 1999). Pavolini was executed by the partisans in 1945 and subsequently hanged upside down in the 
Piazza Loreto in Milan, alongside Mussolini and others. This message indicated that these events were far from forgotten by neo-fascists in contemporary Rome and was designed to anger and provoke their antagonists from the far right

\section{NE' U.S.A. NE' ISLAM etc}

These messages were on the corner of a grey coloured wall in Prati. This image depicts a series of interrelated pieces of graffiti as well as several tags. The message [which means 'NEITHER AMERICA NOR ISLAM'] was painted in black. This strongly suggests that it had a far right connotation. This interpretation is reinforced by the two black tridents below the main message and by the message 'PRATI'. Prati is an inner urban zone close to the Vatican and is also a traditional centre of support for both neo-fascism and SS Lazio. Tridents are also symbols of the far right in Italy [and elsewhere] and are based upon Waffen SS insignia (see Williamson, 2004).

\section{JUDEN RAUS}

This graffiti was situated on a salmon pink coloured door to a telephone booth in Prati. The phrase 'JUDEN RAUS' is German in origin and means 'JEWS OUT'3. The phrase achieved international notoriety as a result of the Holocaust during the Second World War and is associated with extreme anti-Semitism. The capital lettering in the message is written in sky blue - the colour of the shirt worn by SS Lazio. This imagery reveals the interpenetration of football and politics in Rome, and by extension, in Italy as a whole (see Dal Lago, 1990; Francesio, 2008 and Porro, 2008).

\section{ULTRAS LIBERI}

This graffiti was written on a low white painted wall immediately above a roadside kerb in Prati. The expression 'ULTRAS LIBERI' is written in capital letters in sky blue and has a Swastika symbol immediately to the right in the same colour. On the top of the wall 'MONO' is also written in the same colour in capitals. The expression 'ULTRAS LIBERI' literally means 'FREE ULTRAS'. This could mean either 'Free Ultras' or 'Free the Ultras' or both. It represents a rejection of the efforts by the Italian political

\footnotetext{
${ }^{3}$ Juden Raus" ["Jews out!"] was a phrase shouted by the Nazis throughout the ghettos when they were trying to capture Jews in hiding.
} 
authorities to curb and control hard core football supporters [ultras] across Italy (see Foot, 2006 and Agnew, 2007), some of whom have been imprisoned (see Pozzoni, 2005). The Swastika and colour-coding indicate once more the intimate interconnection between football support and politics in the city, even away from the immediate vicinity of the Stadio Olimpico. 'MONO' probably refers to the nickname of one of the Lazio ultras ${ }^{4}$.

\section{PAOLO DI CANIO/ ULTRAS LIBERI etC}

These eight graffiti were located on the back wall of a florist's kiosk in Prati. All eight were sprayed in sky blue capital letters on a light yellow background. They illustrate once again the interpenetration of politics and football support in Rome. 'PAOLO DI CANIO' refers to Paulo di Canio, the famous striker for SS Lazio. He achieved notoriety when he gave a 'Saluto Romano' [a Fascist salute] to the AS Roma fans in the Stadio Olimpico at the end of the Lazio-Roma derby in 2005. His name features again ['AVE PAOLO': 'PRAISE BE TO PAOLO'] in the mid-left of the picture beneath the 'GRUPPO

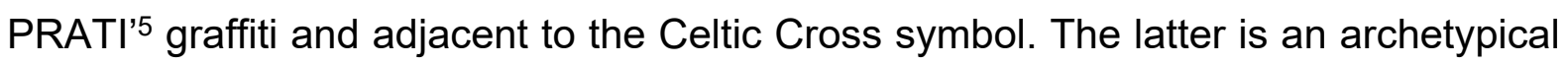
fascist symbol in Europe with origins in Nazi mythologies about Aryan religion. Above these three interrelated messages is the simple expression 'ROMA MERDA'. This refers to AS Roma who feature once again in the bottom right of the picture. Here the insult is more offensive with the use of the phrase the 'ROMANISTA EBREO'. This anti-semitic taunt [it charges that AS Roma fans are Jewish] is common in Rome ${ }^{6}$.

In the middle of the picture is the phrase 'CURVA NORD' which has been underlined. This refers to the area in the Stadio Olimpico that is the home end for fans of SS Lazio7. In the bottom left hand corner is 'LA SQUADRA NEGRI': the name of a group of Lazio Ultras with neo-Fascist leanings. In the top right-hand corner is the expression 'ULTRAS LIBERI' once more.

\footnotetext{
${ }^{4}$ The film Ultra' (2009) showed that prominent ultras in Rome all used nicknames as part of their struggle with the Italian police.

${ }^{5}$ Gruppo Prati are one of the most prominent Lazio Ultra groups in Rome.

${ }^{6}$ See Foot (2006) chapter 11, pp 330-331.

${ }^{7}$ AS Roma fans occupy the Curva Sud.
} 


\section{ONORE AL DUCE}

The main message 'ONORE AL DUCE' was written in black capital letters on grey stone/concrete material at the base of a wall in the Piazza Augusto Imperatore. ${ }^{8}$ The message means 'HONOUR TO THE DUCE' or in other words, 'HONOUR TO MUSSOLINI'. It is superimposed on an earlier, wider black sprayed capital 'M' which is reminiscent of the twin arches of McDonald's, but also is the first letter of Mussolini's surname. The main message has been modified in sky blue in three places. The first letter ' $O$ ' has been extended like the capital letter ' $A$ ' although, more playfully, it also looks like a girl's head with plaits. The second letter ' $O$ ' has been modified in a less ambiguous fashion: the anarchist symbol has been superimposed. Finally, 'DUCE' has been half-heartedly crossed out, but not in an effective fashion. All three changes to the main political message are coloured sky blue which is surprising given the regular conjunction of black and light blue within neo-fascist graffiti in Rome.

\section{VOGLIAMO TUTTO}

The central piece of graffiti in this photograph involves a stencil of a human torso and head with a clenched, raised right fist, sprayed in red, on an ivory coloured wall in the Via Cavour. The expression 'VOGLIAMO TUTTO' means 'WE WANT IT ALL'. It was written in capitals and is part of the overall stencil. It is almost certainly a message from an anarchist or situationist group. On either side are tags, one in sky blue and one in black. Neither of these covers any part of the central stencil.

\section{NO WAR NO WALL / REDS SCUM}

The original graffiti 'NO WAR NO WALL' was written in red capitals at the base of an ivory-coloured wall in the Esquilino area just off the Via Cavour. It is written in English. It also has two female intersecting symbols for females also in red, immediately to the right of the main message. These elements strongly suggest that the graffiti is from a left wing lesbian group. The original message has been overwritten in black capitals in English once again with the words 'REDS SCUM', whilst the lesbian motif has been overwritten with a black Celtic Cross with 'FN' immediately adjacent. FN refers to Forza

\footnotetext{
${ }^{8}$ The Piazza Augusto Imperatore was constructed anew during Mussolini's rebuilding programme in Rome during the 1930s. Mussolini planned to be buried next to Augustus in this Fascist-designed square.
} 
Nuova which is a far right political party founded by Fiore and Morsello in 2003. This is clearly a conversational piece with competing political messages once again equally in evidence. This feature will be examined further in the subsequent discussion of the wider aspects of these images.

\section{ANARCHIST SYMBOL}

The Anarchist symbol has been painted in red on a burnished bronze metallic sign on a wall in the Via Cavour. The sign is for the 'Federazione di Roma e del Lazio Sindicato Lavoratori Commercio Turismo e Servizi' ${ }^{9}$ which is part of the service sector trade union FISASCAT ['Federazione Italiana Sindicati Addetti Servizi Commerciali Affini': 'The Italian Federation of Workers' Trade Unions, Business Services and Allied Industries']. FISASCAT is itself part of the CISL ['Confederazione Italiana Sindacati Lavoratori: 'Italian Confederation of Trade Unions'] which is the second largest trade union federation in Italy ${ }^{10}$ and was closely allied historically to the Christian Democratic Party. The latter dominated the Italian political system from the end of World War II until the collapse and swift demise of the party in 1994 amid a series of corruption scandals ${ }^{11}$. The CISL and its affiliates remain the 'bête noire' of the Italian left.

\section{Buenos Aires 2016}

\section{A 6 ANOS LA MISMA LUGHA EL MISMO ENEMIGO/ POLLO}

\footnotetext{
9 'The Rome and Lazio Federation of Workers in Commerce, Tourism and Services'.

10 It has 4.2 million members.

11 'Tangentopoli' and 'Mani Pulite' were the most prominent
} 
There were two main graffiti on this grey concrete drinking fountain in the Plaza Congreso, which is situated at one end of the street [Avenida de Mayo] that leads from the Argentinian Parliament to the Presidential Palace [Casa Rosada]. The top message in black capital lettering is a stencil 'A 6 ANOS LA MISMA LUGHA EL MISMO ENEMIGO'. This means ' 6 YEARS THE SAME BATTLE THE SAME ENEMY' and is a political message, almost certainly from the left. The 6 years refer to the recent period of economic and political crisis in Argentina.

'POLLO' signifies 'CHICKEN' and is the term of abuse used by Boca fans for their arch-rivals, River Plate ${ }^{12}$ and refers to their perceived lack of guts. It is written in capitals and sprayed in blue, one of the colours of the Boca Juniors Shirt.

\section{BASTA DE POLICIAS EN LAS ESCUELAS/ EN LA CALLE PRENSA ANARQUISTA}

These messages were written on the base of a grey door column on the Avenida de Mayo. The message 'BASTA DE POLICIAS EN LAS ESCUELAS' is written in red capitals and sprayed through a stencil. It means 'END TO POLICE IN SCHOOLS'. This could mean the removal of the police from schools [and/or Universities] or it could be a more radical critique of schools as part of the repressive ideological state apparatus (see Althusser, 1971 and Lewis, 2005). It is superimposed on an earlier message written in yellow which is indistinct [yellow on a grey background is not the best of colour contrasts!]

Below these two messages is a separate stencil with a black flag surrounded by the message 'EN LA CALLE PRENSA ANARQUISTA' which signifies 'ANARCHIST THINKING [OR THOUGHT] IN THE STREET'. This probably means either that the street is the main site for anarchism or that the streets belong to the anarchists or both.

\section{DEMOCRACIA DICTADURA LA REPRESION CONTINUA}

This black stencilled graffiti is also located on a grey wall on the Avenida de Mayo. The message 'DEMOCRACIA DICTADURA LA REPRESION CONTINUA' means 'DEMOCRACY DICTATORSHIP THE REPRESSION CONTINUES'. This refers to the

\footnotetext{
${ }^{12}$ River and Boca are the two biggest football clubs in Argentina. Their derby game is referred to as the 'Superclásico'.
} 
perceived continuation of repressive measures and methods under the current democratically-elected Government in Argentina. This elision of democracy and dictatorship is a persistent trope within left wing theorizing and demonology, particularly in Argentina.

\section{DONDE ESTA?}

This black stencilled image on a travertine-faced wall on the Avenida de Mayo represents the head of Julio Lopez. It also asks 'DONDE ESTA?' which means 'WHERE IS HE?'. Lopez was a key witness at the trial of Miguel Etchecolatz, a prominent member of the Argentinian junta involved during the 'Dirty War' ['Guerra Sucia'] after 1976 that led to thousands of people disappearing and being subsequently murdered at the hands of the regime (see Guest, 1990; Taylor, 1997 and Lewis, 2001). Lopez himself disappeared in 2006 just before he was due to give evidence in court against Etchecolatz. As yet there is no news of his whereabouts but many Argentinians believe that he was murdered in retribution for his testimony.

\section{Red Star [5 pointed red star]; PRT + LOPEZ}

These images were located on a grey concrete wall on the Avenida de Mayo. PRT signifies the 'Partido Revolucionario de los Trabajadores' ['Workers' Revolutionary Party']. This was a Trotskyite political party in Argentina that was prominent in the 1960s and 1970s. In 1968 it founded a related rural guerilla movement [ERP: 'Ejército Revolucionario del Pueblo' - 'People's Revolutionary Army'] which became a powerful force in the countryside. Both the PRT and ERP were suppressed during the 'Dirty War'. Its symbol is a five pointed red star, a classic symbol of the far left.

The two prominent red sprayed graffiti were superimposed on three smaller stencils in a pinkier tint of red. One of these refers to Lopez again and features his face. The other two are now indistinct but in all likelihood contained earlier messages that paralleled the Lopez motif.

\section{POLICE CARS 1976/2008}

These two red stencilled images were located on a portico on the Avenida de Mayo. The upper image represents two secret policemen in 1976 - the year when the Argentinian junta seized power in a coup. The image below shows two policemen in 
an almost identical car: only the number plate [2008] is different. This horizontal diptych suggests once more that there is no real difference between the contemporary Argentinian police and their predecessors under the military junta. As such they challenge the democratic legitimacy of the current Argentinian Government and are almost certainly from the far left.

\section{GUERRILLEROS ONTOLOGICOS}

This graffiti ['GUERRILLEROS ONTOLOGICOS': 'ONTOLOGICAL GUERRILLAS'] was located at the base of an ivory-coloured wall on the Avenida de Mayo. Guerrilla ontology is a movement inspired by both situationism and surrealism. It emphasises fluidity, change and opposes all fixed forms of thought from whichever ideological perspective. Wilson (1986) argued that guerrilla ontology was closely related to French deconstructionism. Bey (2003) subsequently created the concept of the 'TAZ' [Temporary Autonomous Zone] which he defined as an ontological guerrilla camp: 'the TAZ is a revolt which does not engage with the state, a guerrilla operation which liberates an area: of land, of time, imagination and then dissolves to rebuild in any other place or time, before the State can crush it'. Much of the thinking associated with this cultural movement lies underground and is predominantly anarchist in thrust.

\section{RECONSTRUCCION GUEVARISTA [WITH RED STAR ]}

These black and red graffiti were located on an ivory-coloured wall at the corner of the Teatro Avenida building on the Avenida de Mayo. RECONSTRUCCION GUEVARISTA is a Marxist-Leninist grouping on the far left of Argentinian politics. It is

a 'vanguardist' organization opposed to social democratic politics and particularly to voting in elections. It models itself on the Cuban revolution in 1959 and advocates unrelenting struggle against international capitalism [imperialism]. It has as its symbol the traditional five pointed red star of Communism (see Hodges, 1977).

\section{RECONSTRUCCION GUEVARISTA [WITH RED STAR]/ ANARCHIST SYMBOL / P.D.L./NINGUNA PUTA + TAGS}

This complex set of images was located on the Avenida de Mayo. The RECONSTRUCCION GUEVARISTA [WITH RED STAR] graffiti is identical to that in the previous picture. However, it is surrounded by other political messages and two tags [one in brown and the other in red]. All seven images are neatly arranged in three 
tiers on this fenestral interspace. Immediately below RECONSTRUCCION GUEVARISTA [WITH RED STAR] is an anarchist symbol and below that on the third tier is PDL and a red stencil 'NINGUNA NACE PARA PUTA'. This is a shortened version of the slogan 'NINGUNA MUJER NACE PARA PUTA' ['NO WOMAN IS BORN A WHORE'] which was the title of a radical feminist art exhibition ${ }^{13}$ dealing with sex work at the Centro Cultural Borges in Buenos Aires in 2006.

\section{VIVA HAMAS/ AMAUTA/ RED STAR/ M8 RED STAR $\&$}

These graffiti were located at 953 Avenida de Mayo. They are all written in red. 'VIVA HAMAS' expresses support for Hamas - one of the two main Palestinian political parties. 'AMAUTA' refers to the Peruvian cultural journal published by Josè Mariátegui in the period between 1926 and 1930. Mariátegui was a Peruvian philosopher who remains highly influential amongst contemporary South American socialists (see Gonzalez, 2007). In his seminal Seven Interpretive Essays on Peruvian Reality (1928) Mariátegui argued that socialism should develop organically in South America on the basis of local conditions, particularly upon the traditional forms of collectivism practised by autochthonous 'Indians'. His ideas continue to have a powerful impact, particularly upon the Maoist 'Shining Path'14 and the Túpac Amaru Revolutionary Movement. The two red stars are both five-pointed and represent traditional Marxist-Leninist symbols.

\section{Discussion}

These twenty images reveal the complex nature of graffiti in Rome and Buenos Aires. The photographs were selected as representative of the graffiti within the central zones of the two cities but also for their visual interest per se. In Rome there was clear evidence of a powerful political debate between the far right and the far left. This relates directly to the unresolved political tensions in Italy dating back at least as far

\footnotetext{
${ }^{13}$ See www.mujerescreando.com

14 Mariátegui coined the phrase 'sendero luminoso al futuro' ['the shining path to the future'] about Marxism.
} 
as the civil war between 1943 and $1945^{15}$ which coincided with the final years of the Second World War (see Tacchi, 2007). A sizeable minority of Italians, particularly in Rome, have remained unreconciled to the imposition of democratic politics in 1945 (see Levy, 1996; Gregor, 2006; Bull, 2007 and Mammone, 2010) and have bitter memories of the civil war between the far left and the far right. Memories lie deep. These are particularly strong amongst groups on the extremes of the political spectrum where there is a powerful iconography of martyrdom. The graffiti about 'Pavolini Eroe' [Photograph 2] and the 'Onore al Duce' [Photograph 7] message close to the planned site of Mussolini's tomb both bear testimony to this.

There is also powerful evidence of the interfusion of politics and football support in Italy (see Roversi, 2006; Testa \& Armstrong, 2012 and Doidge, 2013). The identification of the Lazio ultras with neo-fascism is evident in their use of symbols like the Celtic Cross and the trident, both of which derive from insignia used by the SS. Recently, in October 2017, fans of Lazio defaced the Stadio Olimpico with anti-semitic graffiti depicting Anne Frank wearing an A.S. Roma shirt. Their use of the Nazi swastika and their anti-semitism [see Photograph 4 'Juden Raus' and Photograph 6 'Romanista Ebreo'] provides further evidence of this link.

Such graffiti have also generated a reaction from the far left in the form of countermessages. These are colour-coded in red and involve left-wing symbols such as the hammer and sickle. Indeed, several photographs illustrate the 'conversational' form of the political debates on the walls in Rome [see Photograph 2 'Pavolini Eroe' and Photograph 9 'No War No Wall']. In each case the original message has been opposed by a counter message superimposed on the earlier graffiti. However, both remain clearly legible. There has been no attempt to obliterate the original message; rather the writers of the second ['response'] message want their audience to see both elements clearly. This can be seen as a modern equivalent to the messages that have traditionally festooned the 'talking statues'16 in Rome such as the one located within

\footnotetext{
15 It could also be interpreted as part of the ongoing battle between the far left and the far right since the end of the First World War.

${ }^{16}$ From the $15^{\text {th }}$ Century onwards Romans would post messages and counter-messages on the statue of Pasquino in a small square near the Piazza Navona. This was the first 'talking statue' in Rome. The practice spread to other statues in central Rome during subsequent centuries.
} 
the Piazza di Pasquino in the centre of the city. They also parallel the 'conversations' analysed by Lennon (2014) in his research on graffiti produced in Cairo during the Arab Spring in 2011.

Messages were strongly colour-coded in Rome. Black is used for messages from the far right and red for those from the far left. Messages from football ultras, despite their political connotations, are generally coded in the colour of the team's shirts - sky blue for SS Lazio and maroon and yellow for AS Roma.

Political messages were also in evidence in Buenos Aires but they were all antiEstablishment and many were anti-Government. Many were also in the form of stencils. This has been a longstanding feature of Argentinian (see Manco, 2002 and Ruiz, 2008) and other South American (see Palmer, 2008 and Moraes \& Rivas, 2008) graffiti. The dark years of the Argentinian military junta between 1976 and 1983 still underpin much contemporary discourse and imagery [see Photograph 13 DEMOCRACIA DICTADURA LA REPRESION CONTINUA; Photograph 14 DONDE ESTA?; Photograph15 Red Star [5 pointed star ]; PRT + LOPEZ, and Photograph 16 POLICE CARS 1976/2008]. The head of Julio Lopez represents a popular motif in central Buenos Aires and is immediately recognizable to the local inhabitants.

Colour-coding of political messages was also evident in Buenos Aires but in somewhat different ways than the patterns in Rome. Black is also the traditional colour of anarchism and was used in several images [see Photograph 12 BASTA DE POLICIAS EN LAS ESCUELAS/ EN LA CALLE PRENSA ANARQUISTA and Photograph 19 RECONSTRUCCION GUEVARISTA [WITH RED STAR]/Anarchist Symbol/ P.D.L./NINGUNA PUTA + TAGS]. Red - the traditional colour used by Marxists- was also evident [see Photograph 15 Red Star [5 pointed star]; PRT + LOPEZ and Photograph 20 VIVA HAMAS/ AMAUTA/ RED STAR/ M8 RED STAR]. Red combined with black is also a traditional left-wing colour combination, associated particularly with anarcho-syndicalism ${ }^{17}$. It featured in several messages connected with Guevarism [see Photograph 18 RECONSTRUCCION GUEVARISTA [WITH RED STAR] and Photograph 19 RECONSTRUCCION GUEVARISTA [WITH RED STAR]/Anarchist

\footnotetext{
17 See Rocker (1938)
} 
symbol/ P.D.L./NINGUNA PUTA + TAGS which has a strong affinity with the rural elements within anarcho-syndicalism.

Football graffiti was conspicuous by its absence in central Buenos Aires. Even around the Boca and River stadia, there was little football graffiti. The only evidence of such graffiti was the insult 'POLLO' [see Photograph 11 A 6 ANOS LA MISMA LUGHA EL MISMO ENEMIGO/ POLLO]. This had been sprayed in the colour of the Boca shirt. Football support does not have the same political connotations in Argentina as it does in Italy. Attempts have been made to portray Boca as 'working class' and River as 'middle class', in part due to the radically different environments within which each of their respective stadia are located. However, in reality both clubs have enormous popular appeal throughout Argentinian society and football support is not closely connected to political affiliations. This is further borne out in Rosario - Argentina's second largest city - where both local teams [Newell's Old Boys and Rosario Central] claim Ché Guevara as one of their supporters!

The written language of graffiti in Buenos Aires was exclusively in Spanish. In Rome, on the other hand, a wide range of languages were used including Italian, English [see Photograph 1 RED ZONE and Photograph 9 NO WAR NO WALL / RED SCUM]; German [see Photograph 4 JUDEN RAUS and Latin [see Photograph 6 PAOLO DI CANIO/ ULTRAS LIBERI etc]. This is partly the result of the far greater international audience in Rome. The city is one of the world's main tourist destinations whereas Buenos Aires is far less of a tourist attraction currently.

There can be no doubt that graffiti in Rome and Buenos Aires have a meaning. Indeed, as has been shown, these meanings are multiple, complex, layered and rooted in historical events and longstanding collective memories. They make sense hermeneutically to both graffiti creators and to their local audiences. Context is clearly significant and colours resonate differently in the two cities. There is also a remarkable aesthetic 'order' to these graffiti. This is most clearly visible in Photograph 19 RECONSTRUCCION GUEVARISTA [WITH RED STAR ]/ Anarchist Symbol / P.D.L./NINGUNA PUTA + TAGS and Photograph 20 VIVA HAMAS/ AMAUTA/ RED STAR/ M8 RED STAR in Buenos Aires and Photograph 6 [PAOLO DI CANIO/ ULTRAS LIBERI etc] in Rome. In these pictures the various images are clearly, even 
neatly, arranged so as to allow the maximum diversity and impact. Overall, it is clear that graffiti in Rome and Buenos Aires, far from signifying 'disorder', are part of the very ordering of the streets.

What is this order? Graffiti is a form of expression and is associated with marginal political and cultural groups who are routinely excluded from mainstream mass media in both countries. The streets constitute a powerful alternative medium for the expression of their views. Graffiti is also transgressive and unauthorised: it is illegal and normally created at night when the streets are empty. Its creators are elusive and not easy to find. It is a vibrant sub-culture that is intrinsically contestational it is also provocative and challenging. Messages are thought out in advance and considerable effort is made both in the creation of stencils and in the location and ordering of graffiti.

Overall these graffiti provide important insights into the political culture of many young adults in these two cities. They also offer an antidote to the dominant set of meanings transmitted by the mainstream media in both countries. They illustrate the advantages of 'deep descriptions' for an effective understanding of the hermeneutics of visual images and how their wider cultural significance is rooted in the collective memories of recent political events in Italy and Argentina.

\section{Conclusions}

This paper is based upon the deep descriptive coding of two sets of photographs of political graffiti taken in Rome and Buenos Aires. This comparative detailed descriptive approach was central to the generalisations produced. These generalisations were generated inductively through the detailed coding of each photograph in their phenomenological particularities. The intrinsic merits of the analysis of these images lie not in any positivistic notions of typicality but rather in terms but rather in terms of their illustrative and hermeneutic properties. 


\section{APPENDIX 1}

\section{ROMA PHOTOGRAPHS}

\section{RED ZONE}

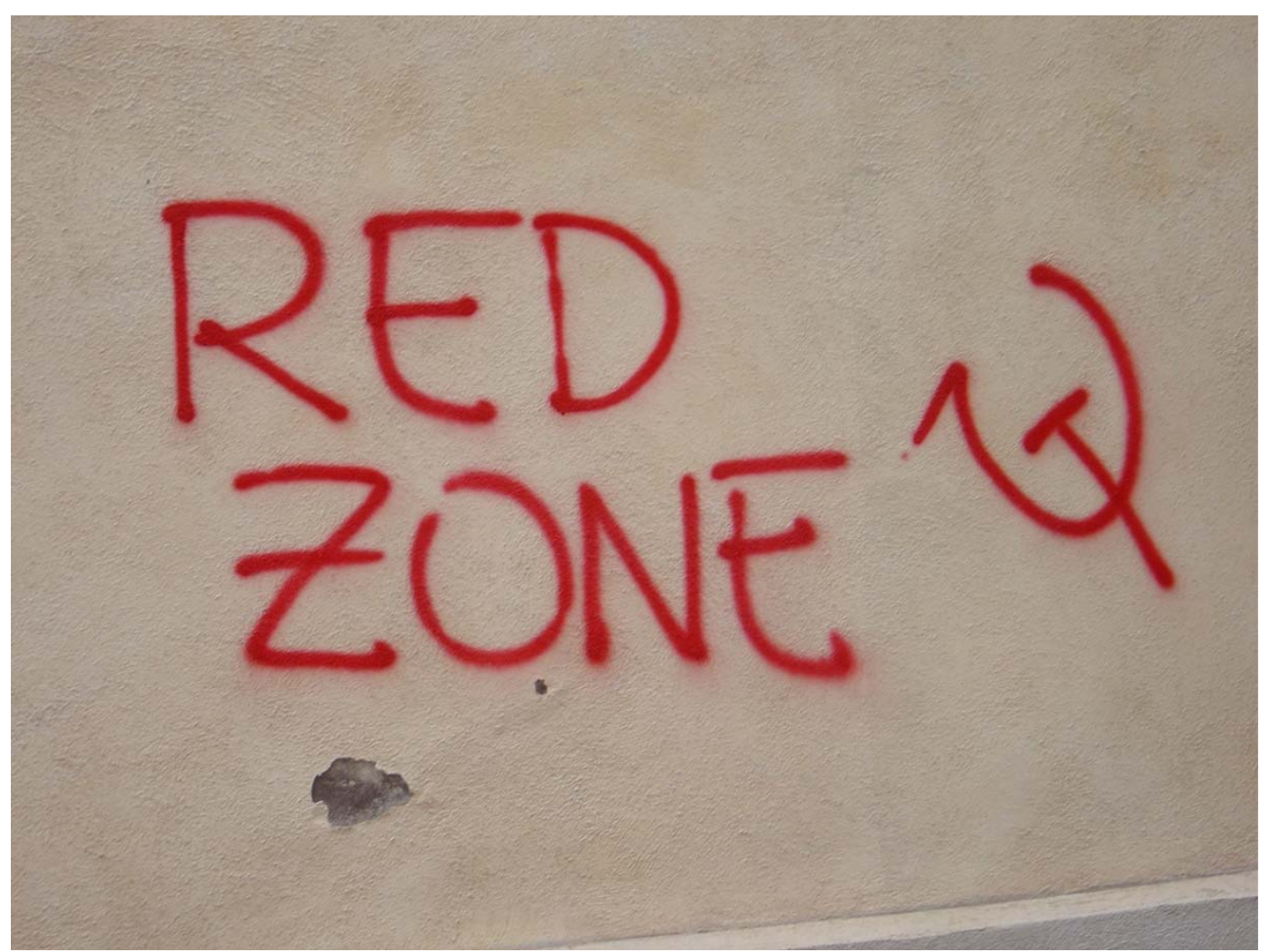




\section{PAVOLINI EROE!}

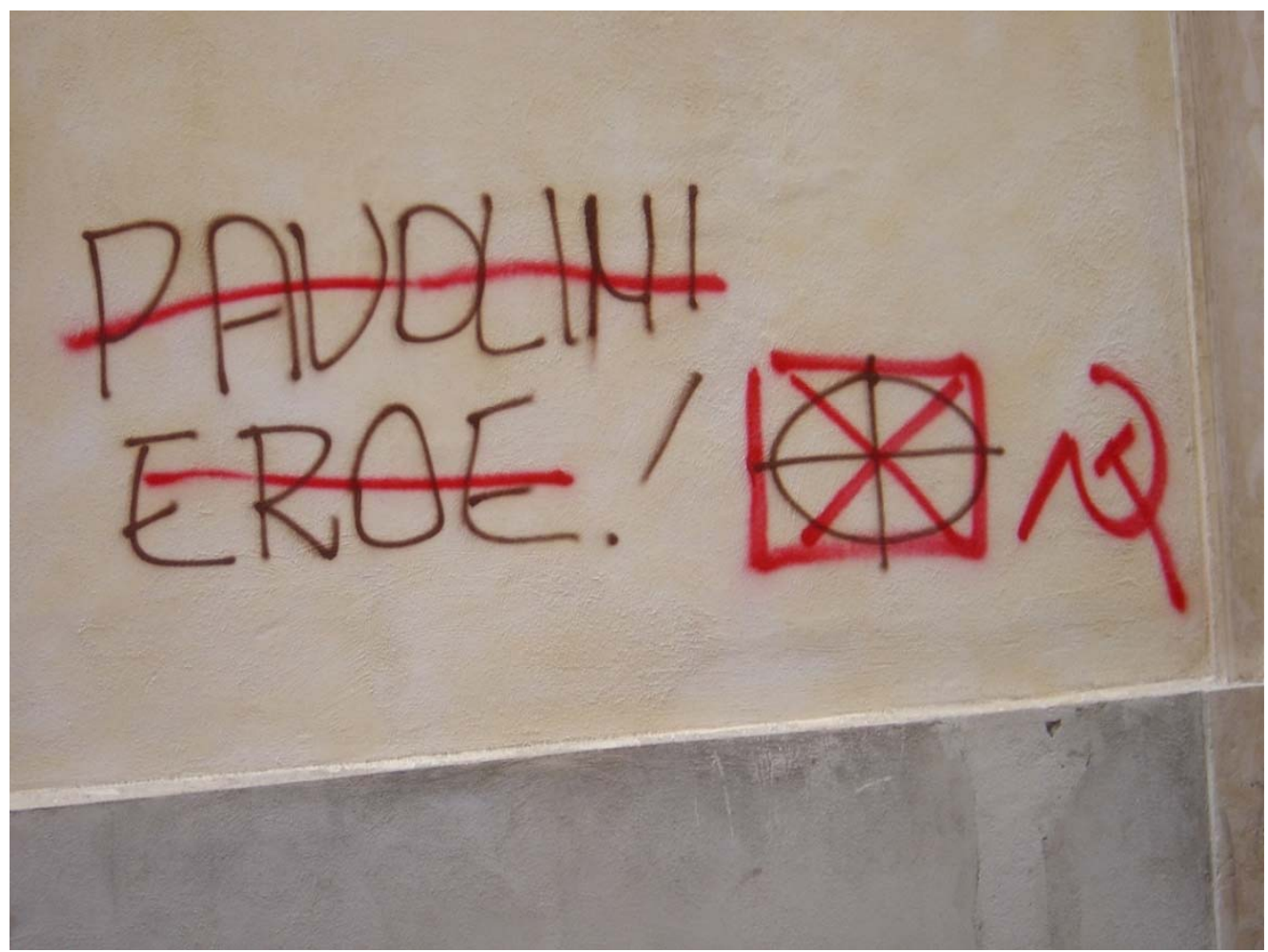


3. NE' U.S.A. NE' ISLAM

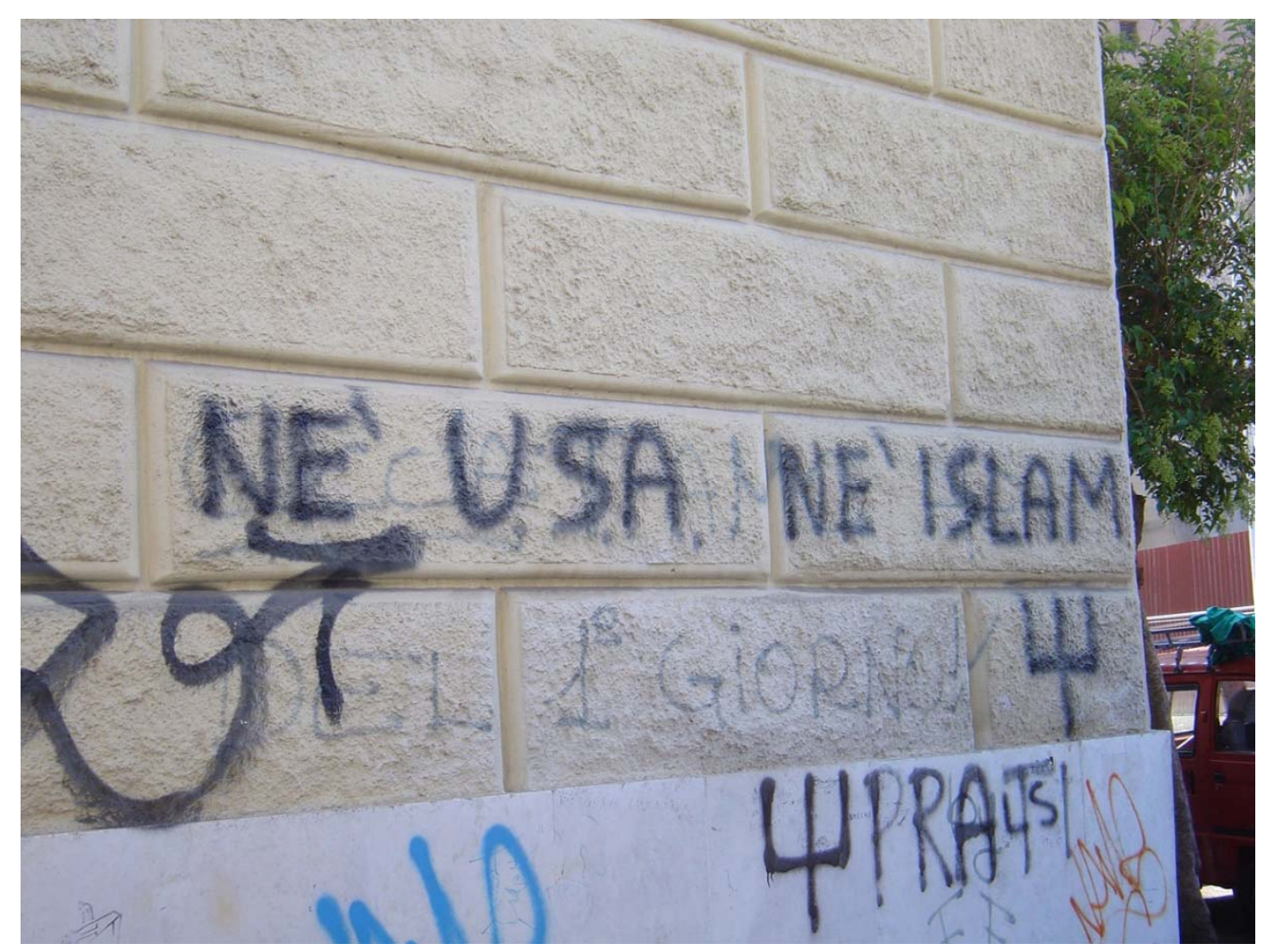




\section{JUDEN RAUS}

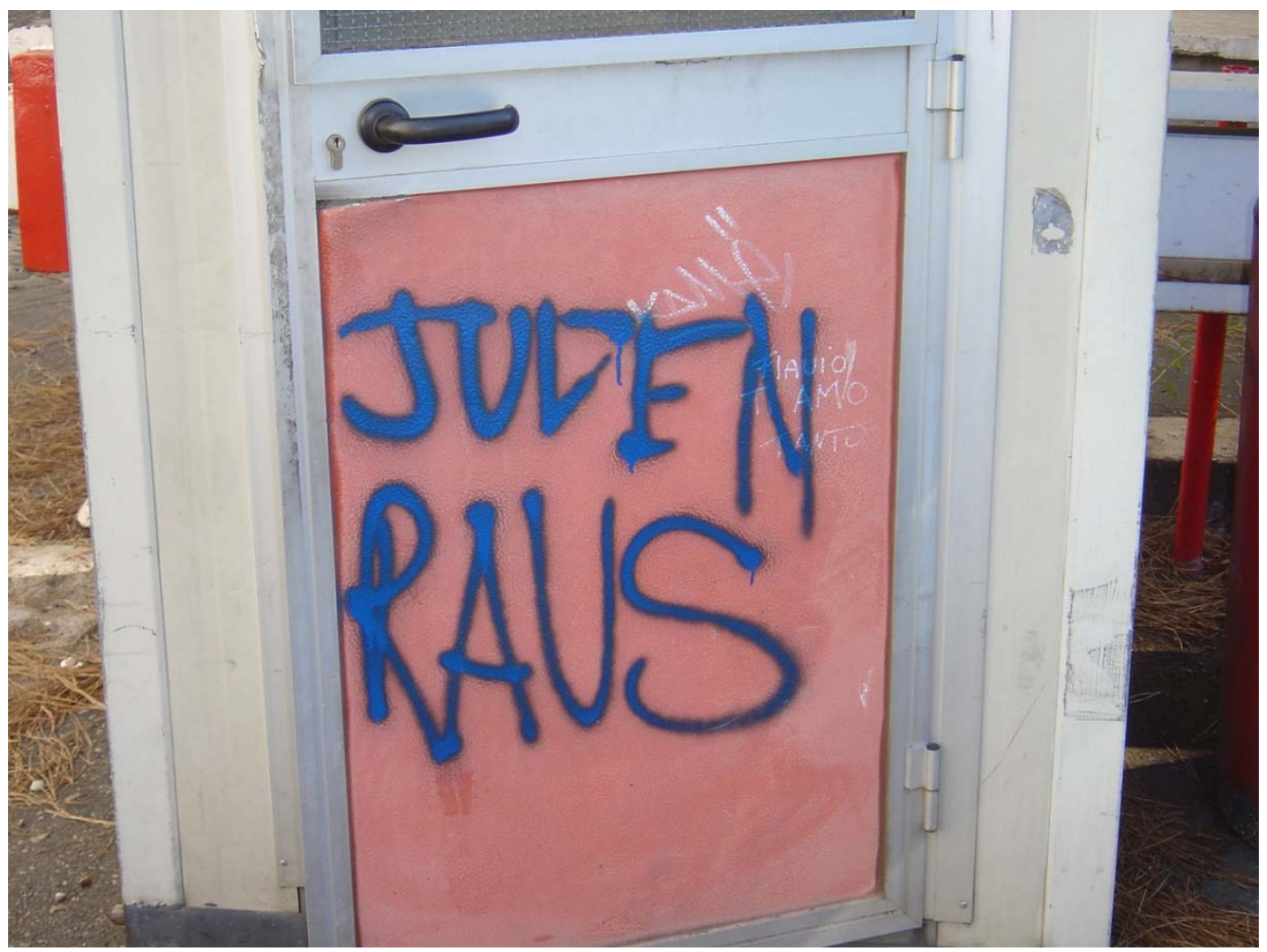

\section{ULTRAS LIBERI}

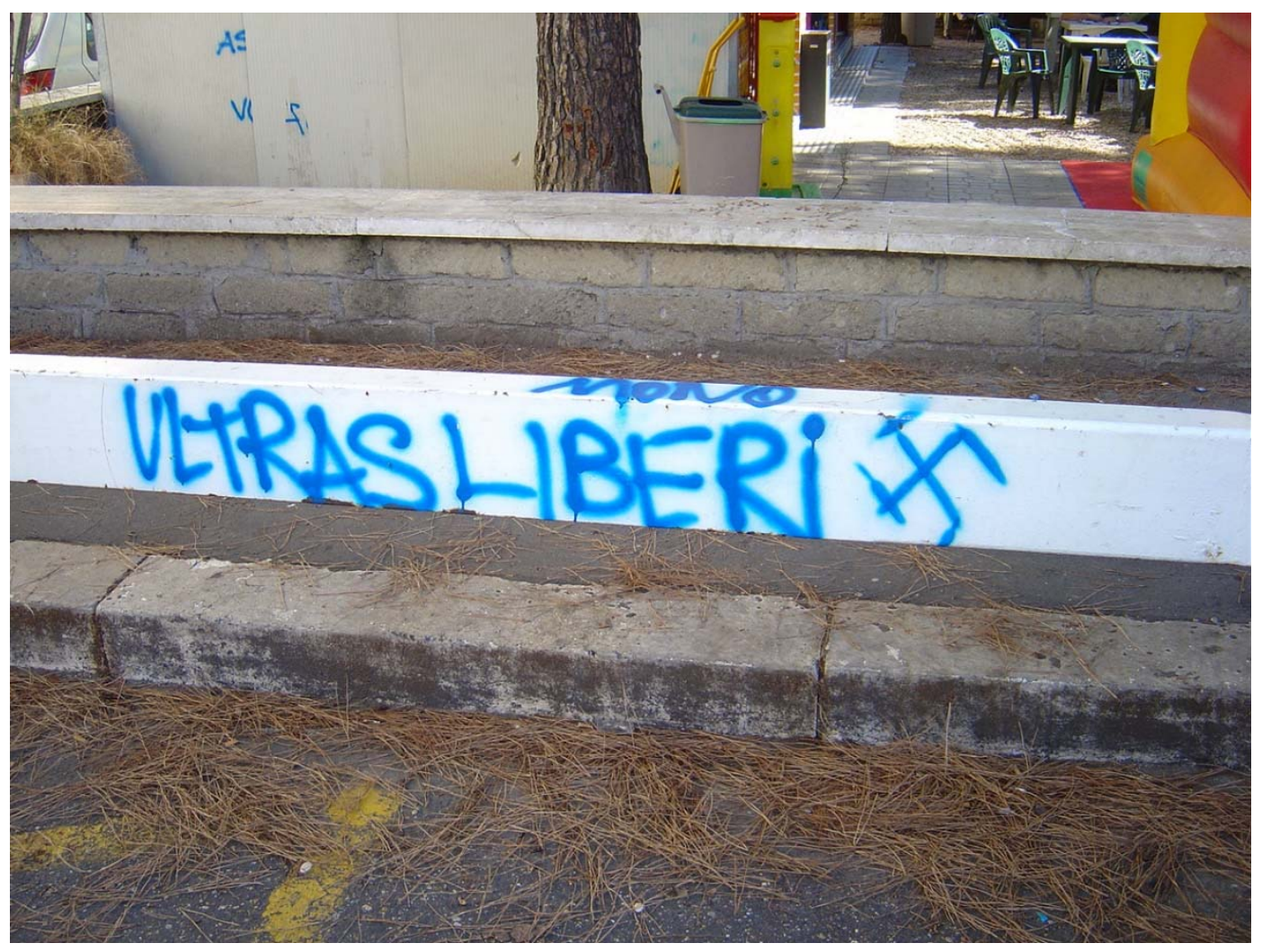


6. PAOLO DI CANIO/ ULTRAS LIBERI etc

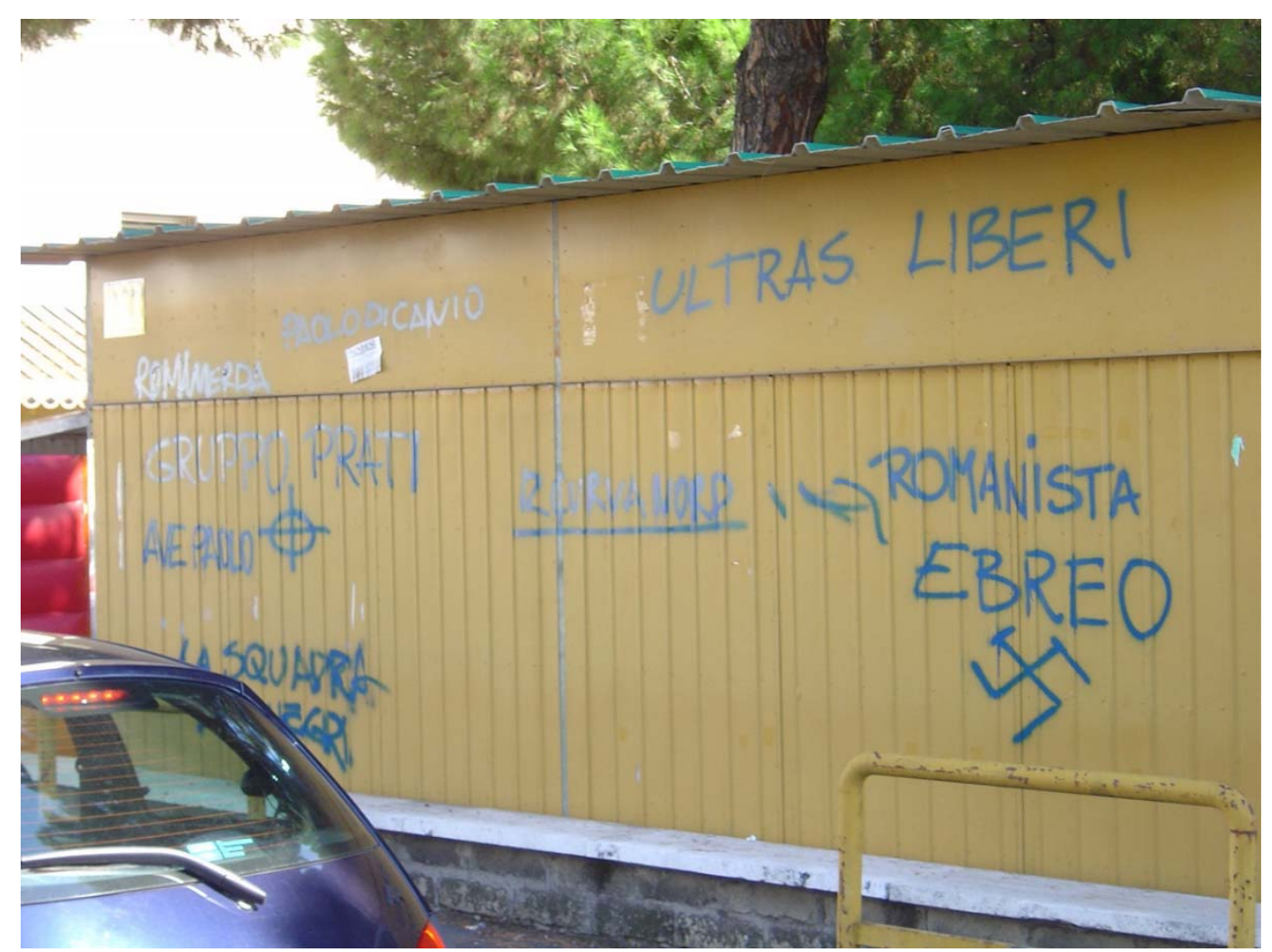

7. ONORE AL DUCE

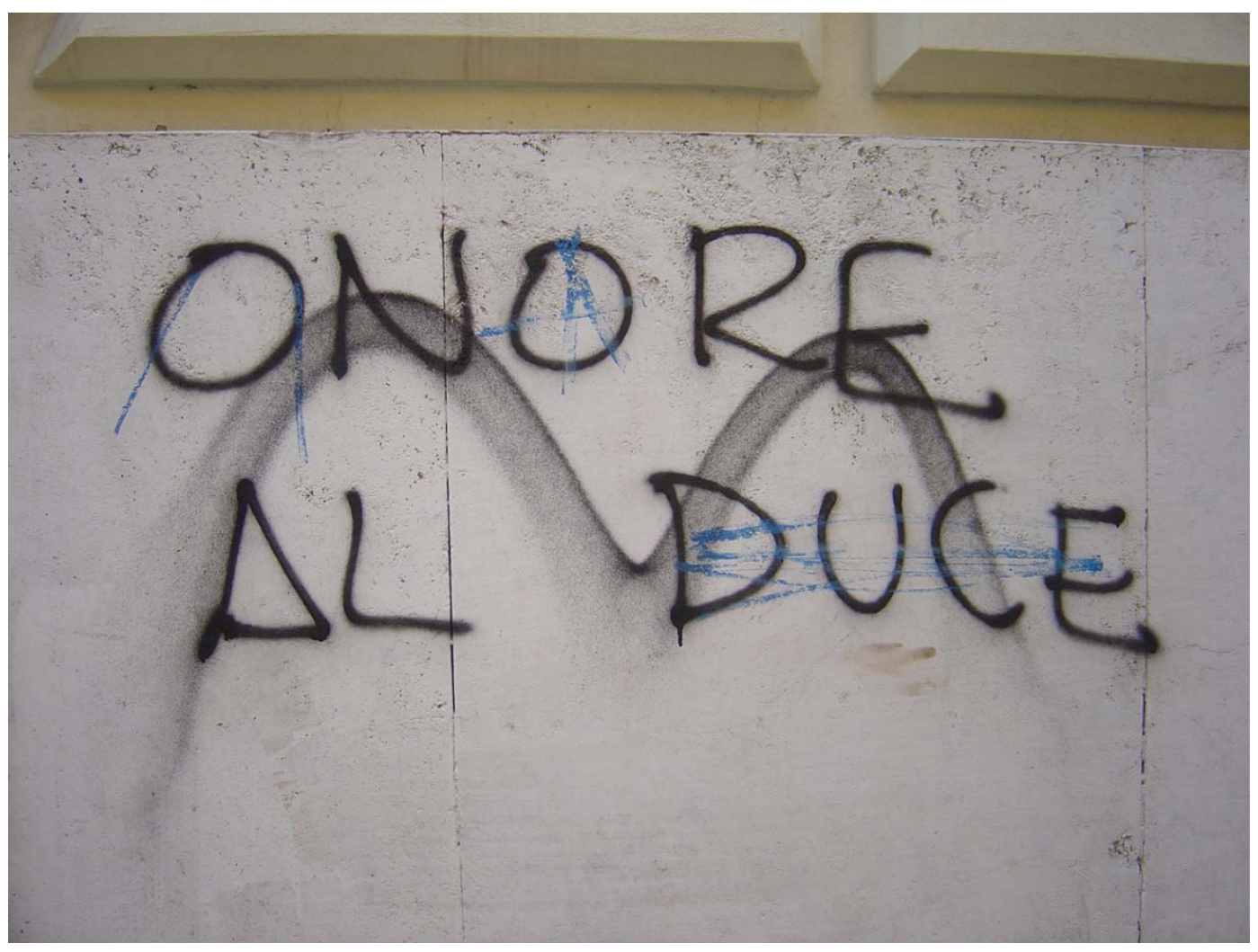




\section{VOGLIAMO TUTTO}

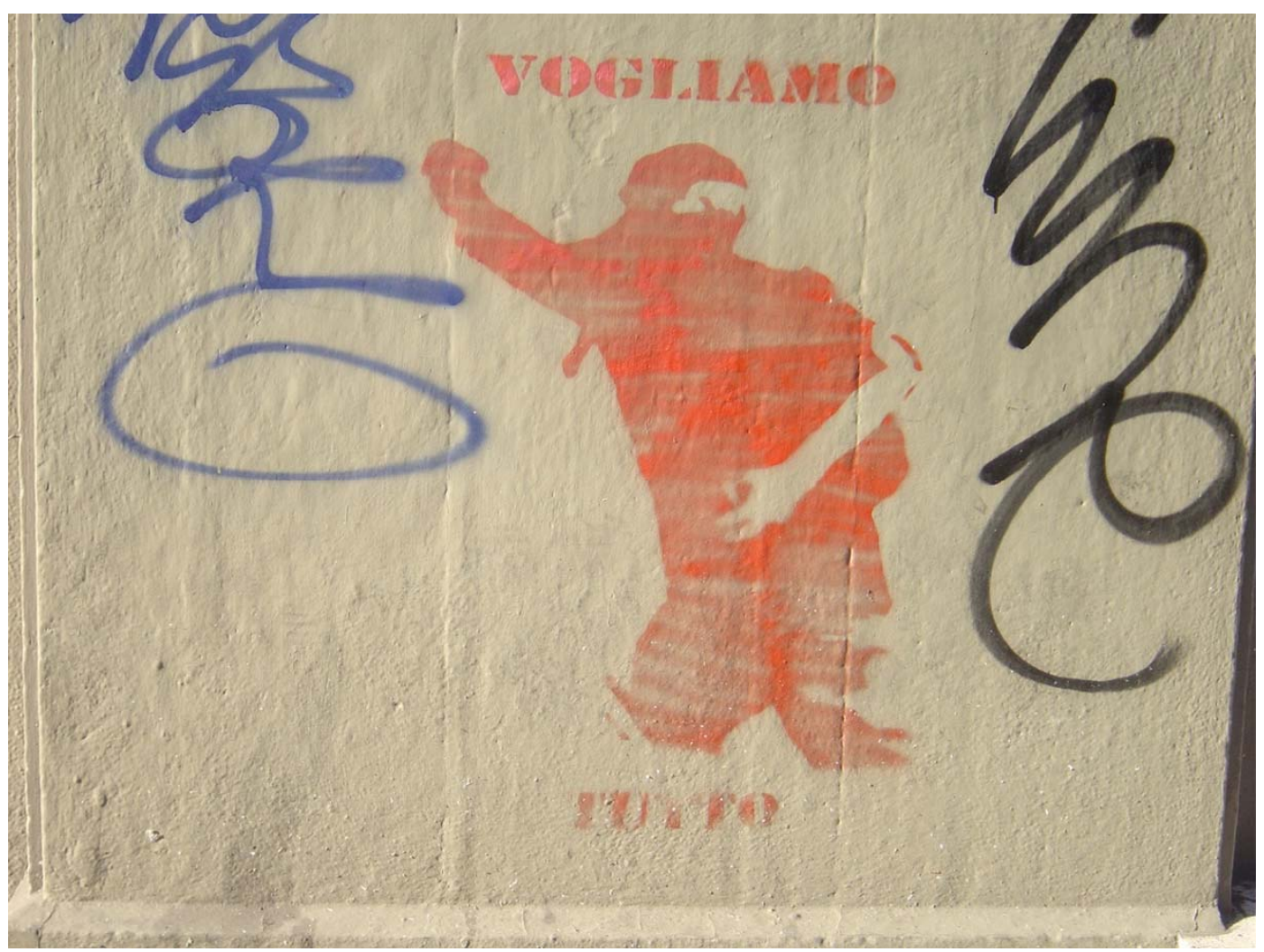

9. NO WAR NO WALL / RED SCUM

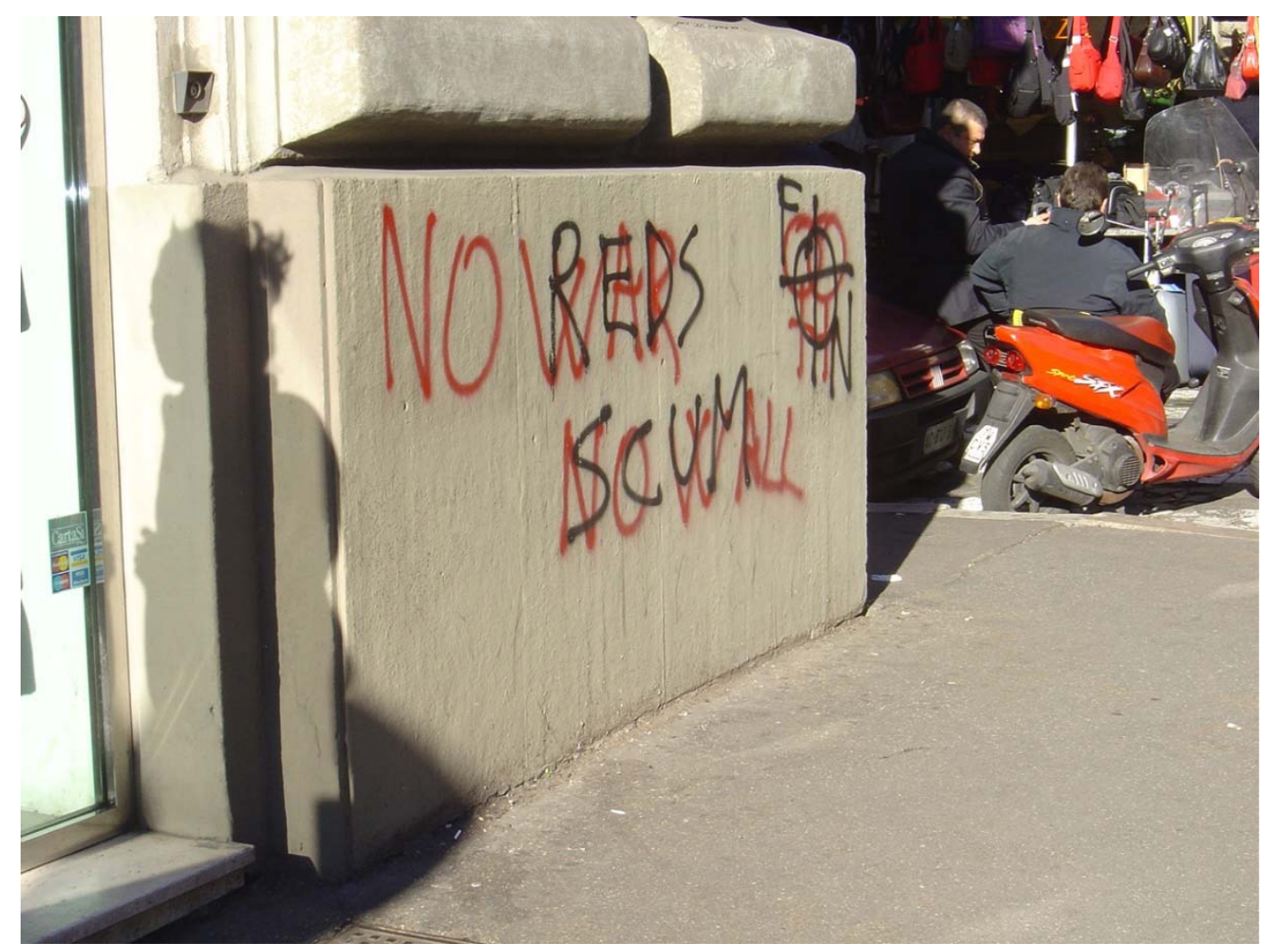


10. ANARCHIST SYMBOL

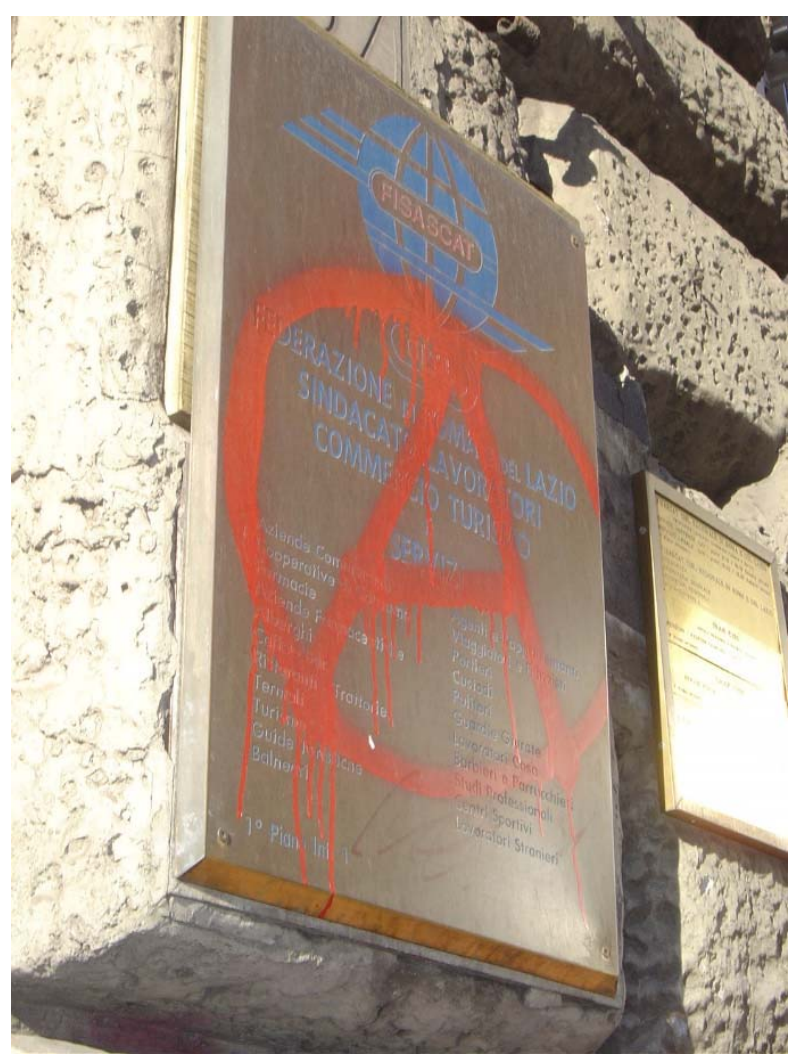




\section{APPENDIX 2}

\section{BUENOS AIRES PHOTOGRAPHS}

11. A 6 ANOS LA MISMA LUGHA EL MISMO ENEMIGO/ POLLO

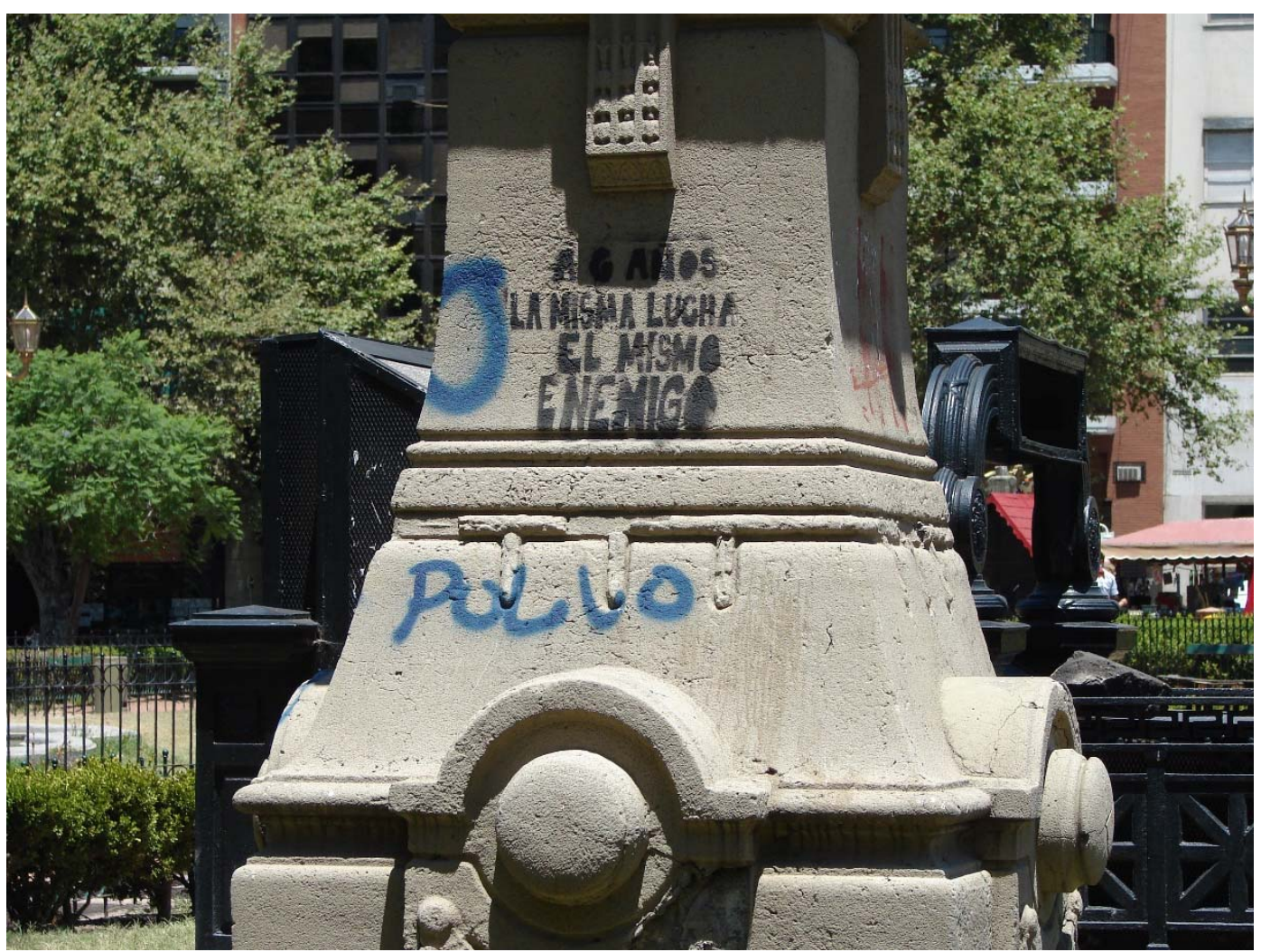


12. BASTA DE POLICIAS EN LAS ESCUELAS/ EN LA CALLE PRENSA ANARQUISTA

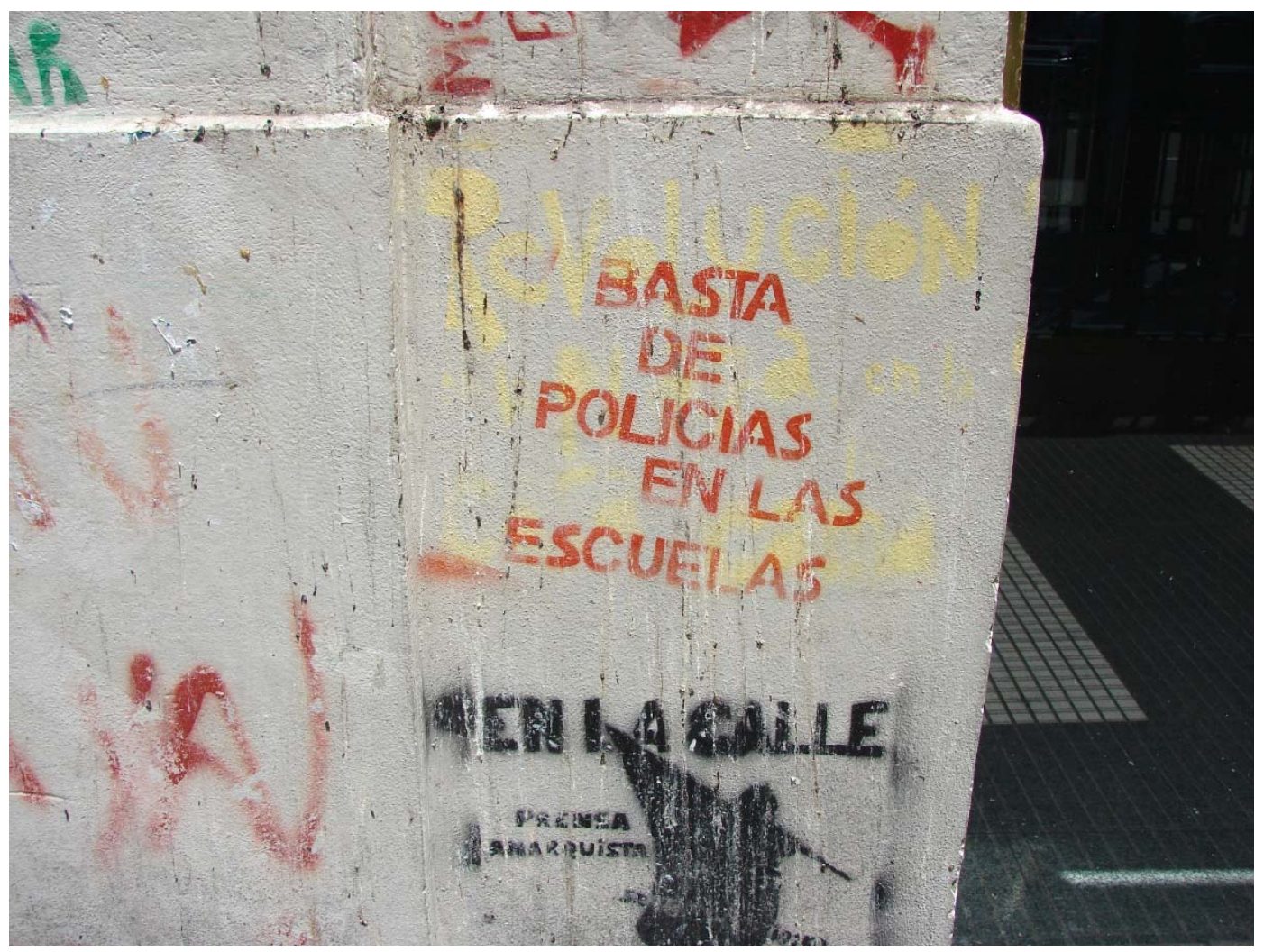


13. DEMOCRACIA DICTATURA LA REPRESION CONTINUA

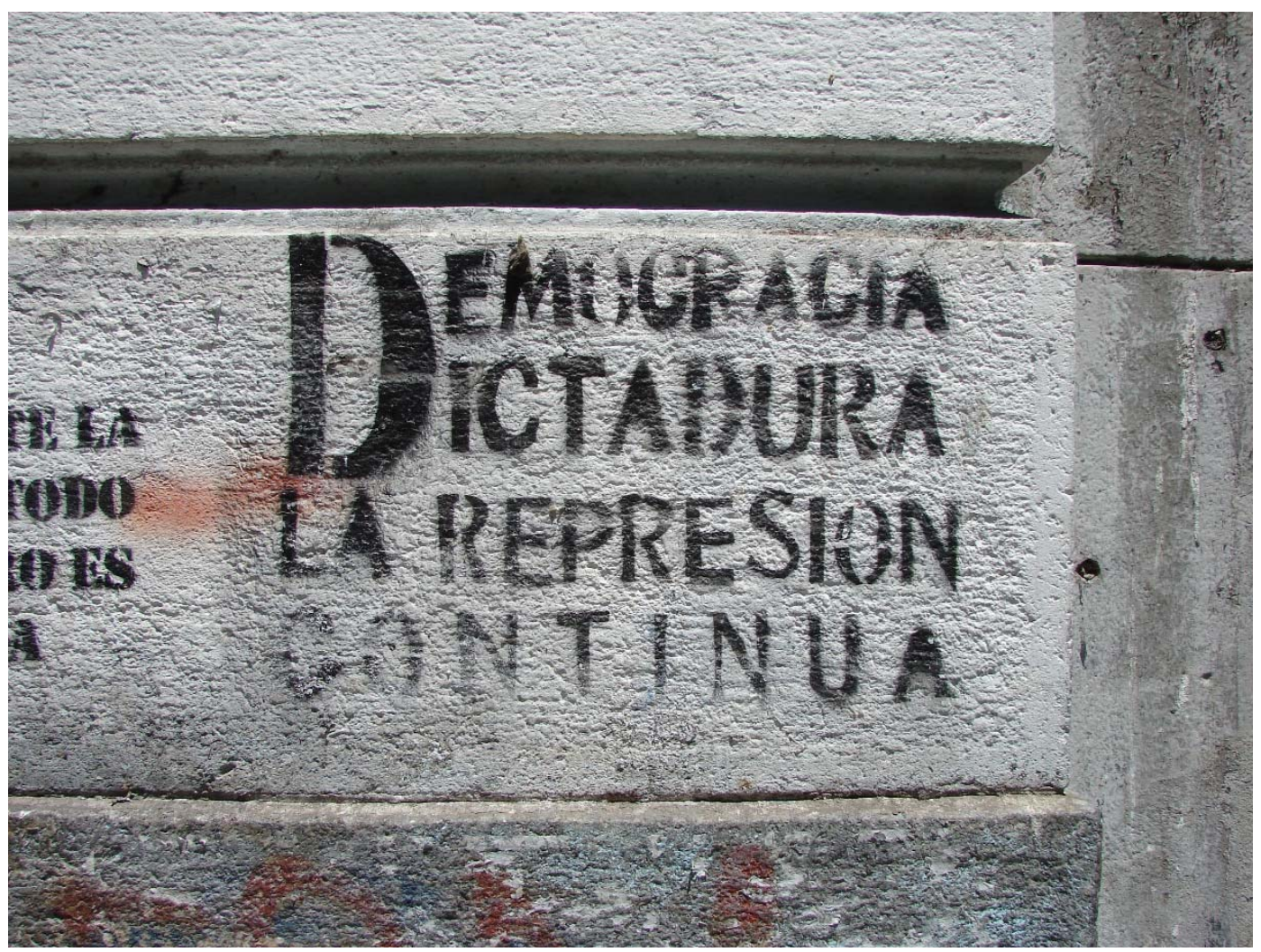

14. DONDE ESTA?

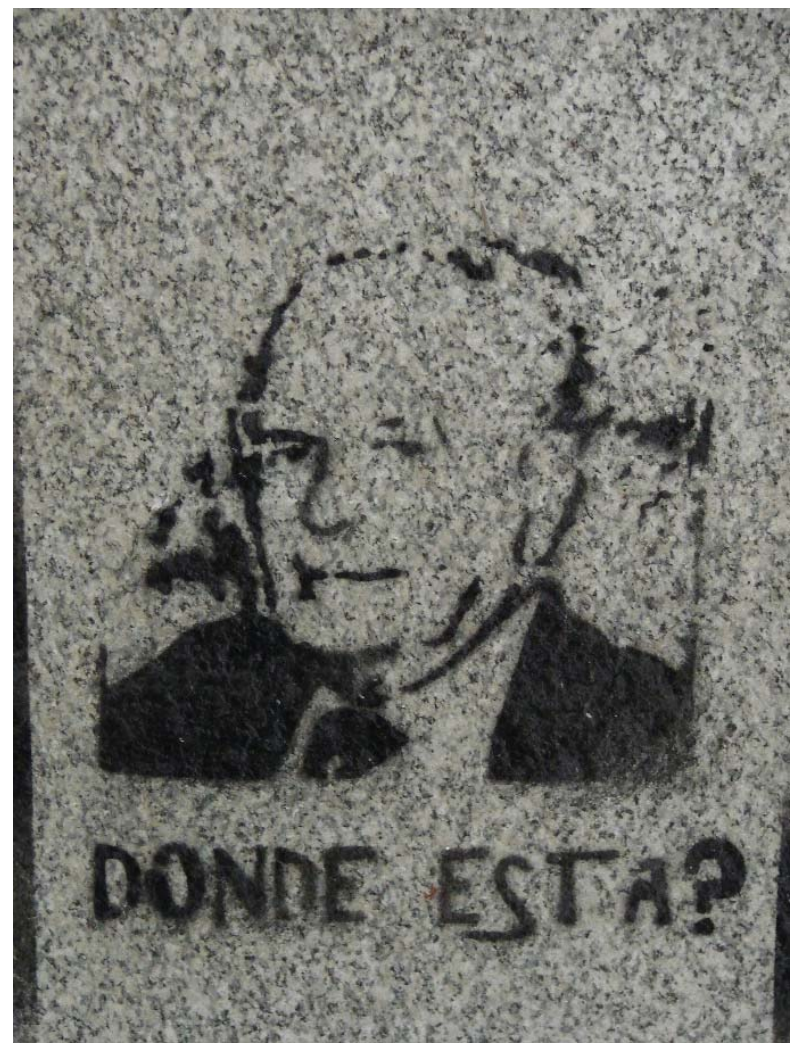


15. Red Star [5 pointed $\Varangle$ ]; PRT + LOPEZ

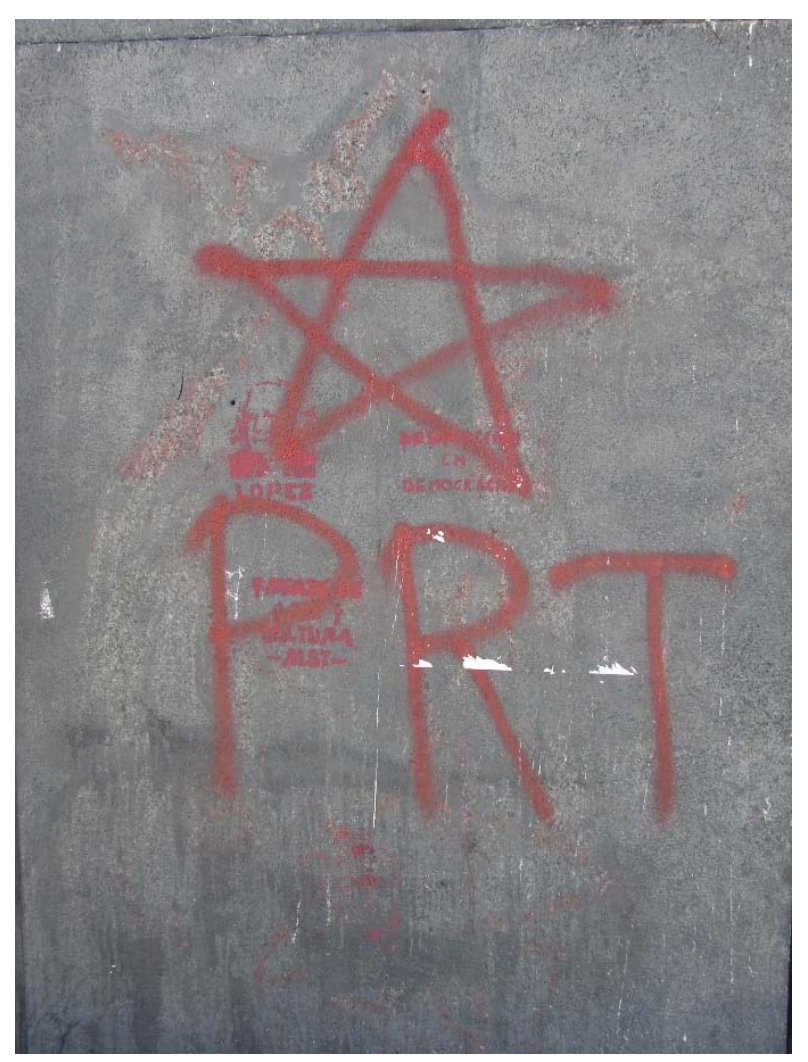


16. POLICE CARS 1976/2008

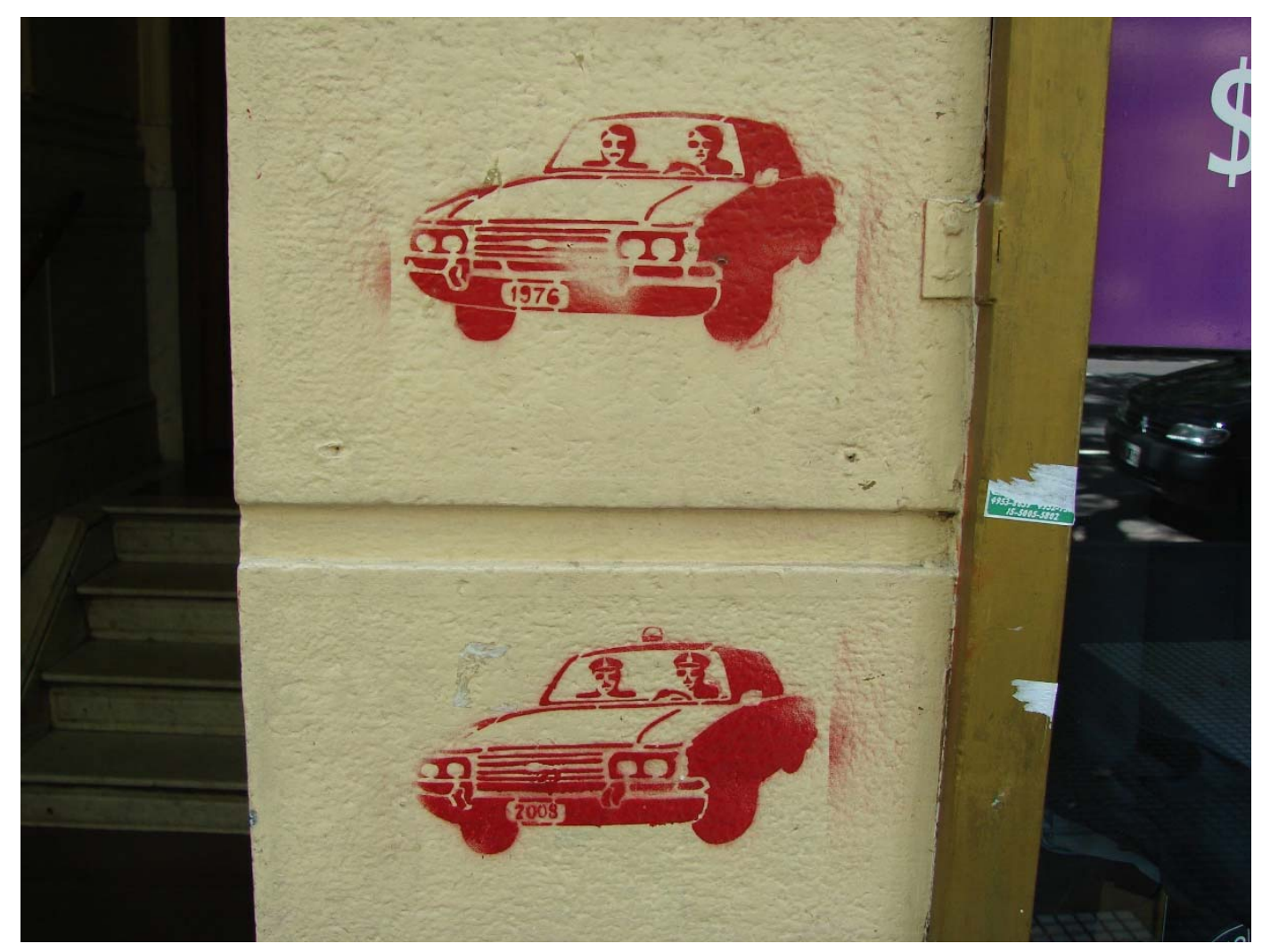

17. GUERRILLEROS ONTOLOGICOS

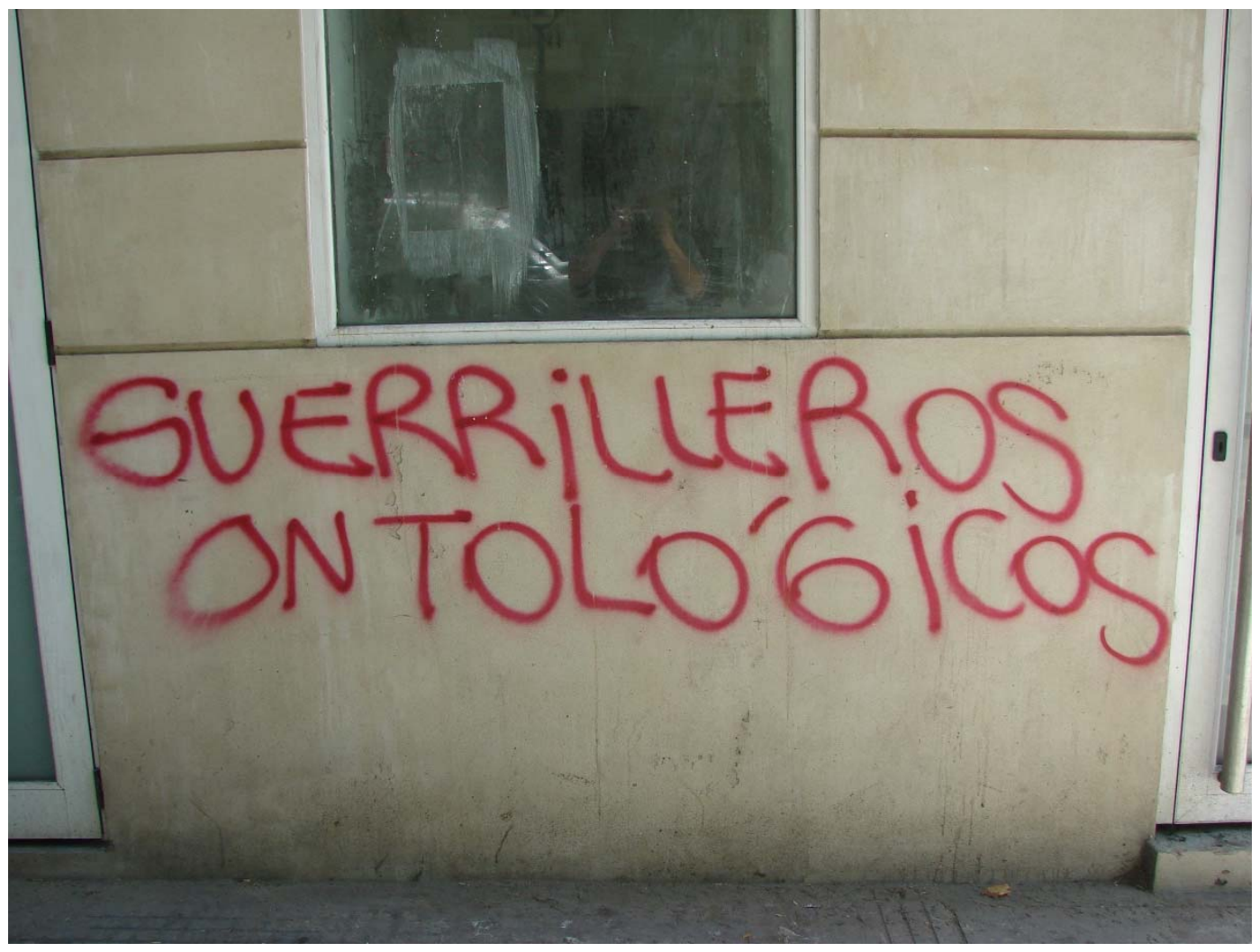


18. RECONSTRUCCION GUEVARISTA [WITH RED STAR \&]

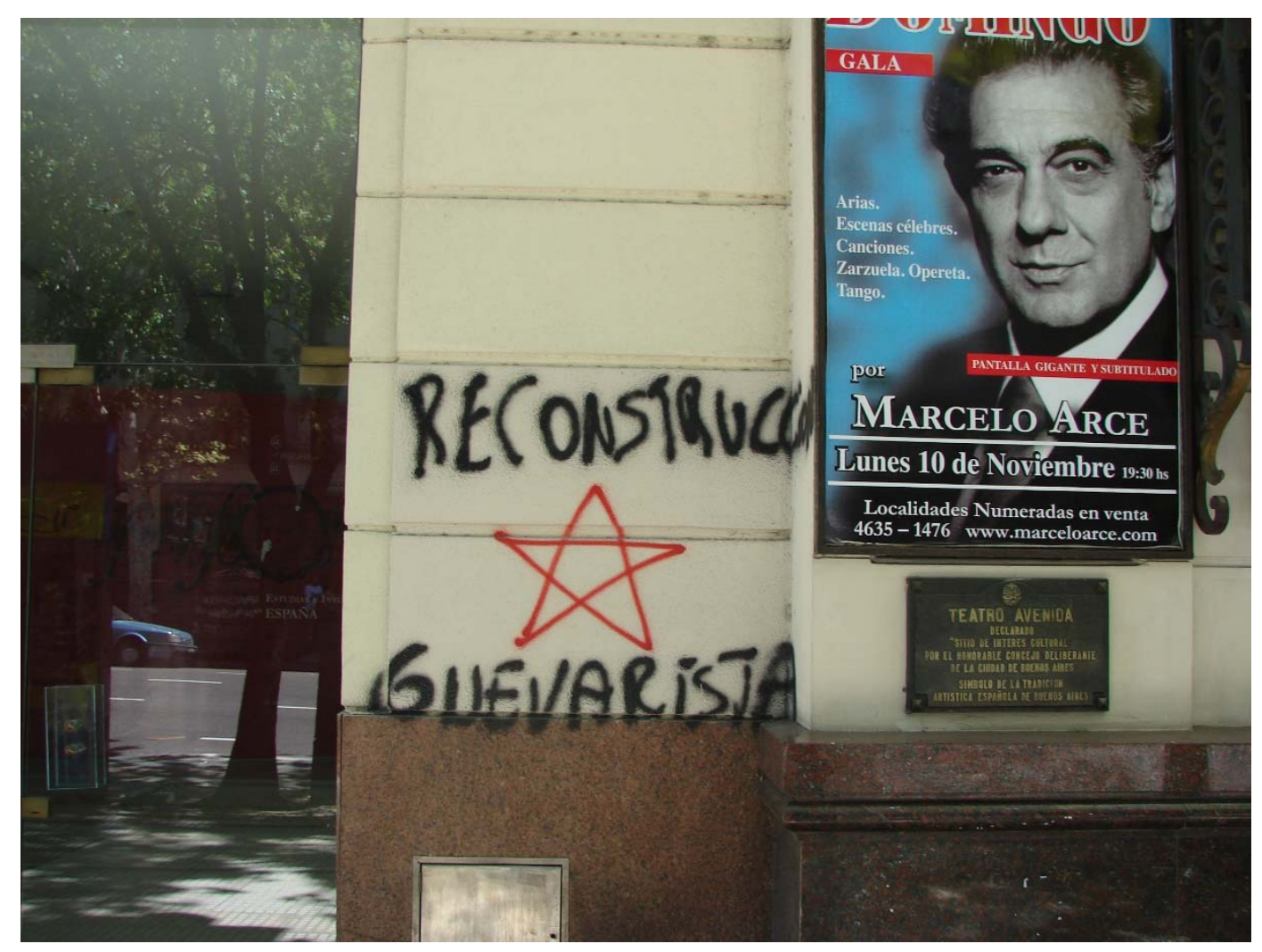


19. RECONSTRUCCION GUEVARISTA [WITH RED STAR \& ]/ $\circledast$ / P.D.L./NINGUNA PUTA + TAGS

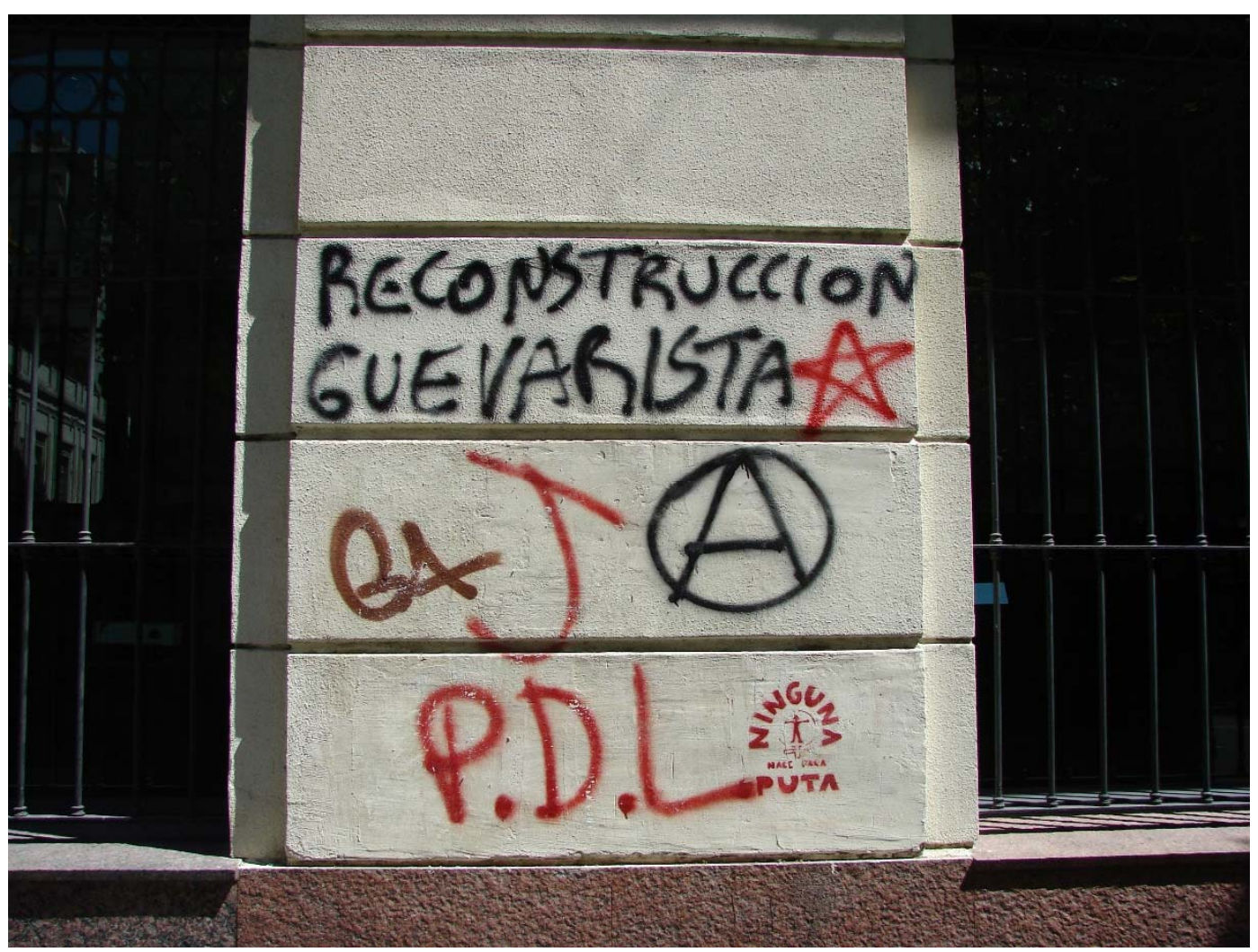


20. VIVA HAMAS/ AMAUTA/ RED STAR/ M8 RED STAR $\Varangle$

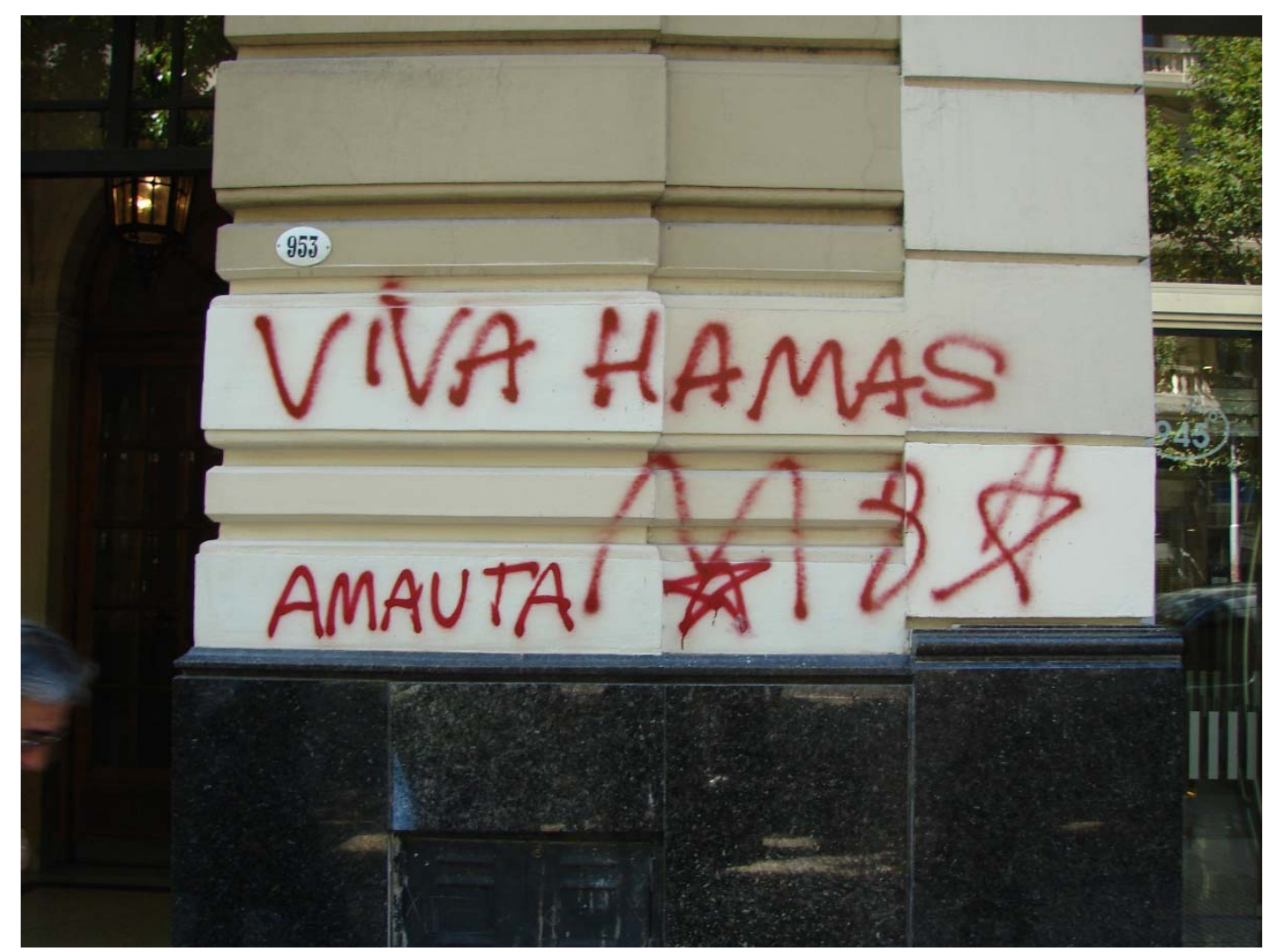




\section{References}

Agnew, P (2007) Forza Italia: The Fall and Rise of Italian Football London: Ebury Press.

Althusser, L (1971) 'Ideology and Ideological State Apparatuses' in Lenin and Philosophy and Other Essays New York: Monthly Review Press

Anderson, E. (1999) Code of the Street New York: WW Norton.

Avramidis \& Tsilimpounidi, M. (2017) [ed] Graffiti and Street Art: Reading, Writing and Representing the City London: Routledge.

Banksy (2005) Wall and Piece London: Century.

Bey H. (2003) TAZ: The Temporary Autonomous Zone, Ontological Anarchy, Poetic Terrorism Williamsburg: Autonomedia.

Bull, A. (2007) Italian Neo-Fascism: the Strategy of Tension and the Politics of Nonreconciliation New York: Berghahn Books.

Castleman, C. (1982) Getting Up: Subway Graffiti in New York Cambridge, MA: MIT Press.

Champion, M. (2015) Medieval Graffiti London: Ebury Press.

Dal Lago, A. (1990) Descrizione di una battaglia: I rituali del calcio Bologna: il Mulino.

Dickens, L. (2008) 'Placing post-graffiti: the journey of Peckham Rock' Cultural Geographies, 15, 471-496.

Doidge, M. (2013) 'If you jump up and down Balotelli dies: Racism and player abuse in Italian football' International Review for Sociology of Sport' International Review for the Sociology of Sport, 50, 3, 249-264.

Evola, J. (1934) Rivolta contro il mondo moderno Milan: F. Burzio.

Foot, J. (2006) Calcio: A History of Italian Football London; Fourth Estate.

Francesio, G. (2008) Tifare Contro: Una Storia degli ultras italiani Milano: Sperling \& Kupfer.

Freda, F. (1969) La disintegrazione del sistema Padova: Edizioni di Ar

Gagliani, D. (1999) Brigate nere: Mussolini e la militarizzazione del Partito fascista repubblicano. Torino: Bollati Boringhieri. 
Ganz, N. (2004) Graffiti World: Street Art from Five Continents London: Thames \& Hudson.

Garfinkel, H. (2007) 'Venerated Things of Football Stadia: Architectural Shrines in Irreconcilably Alternate Details of "Representations" Versus "Descriptive Exhibitions" [Version3/9/07] paper presented to the UCLA-Lancaster University Symposium on 'Sociological Research Methods: Beyond the Quantitative-Qualitative Divide' [available at

http://www.maths.lancs.ac.uk/department/training/esrcRegional/workshops/uclasymp osium2007.]

Giddens, A. (2001) Sociology: Fourth Edition Cambridge: Polity Press.

Gonzalez, M. (2007) 'Jose Maria Mariátegui: Latin America's forgotten Marxist', International Socialism, 117, 21-32.

Gregor, A. (2006) The Search for Neofascism: the Use and Abuse of Social Science Cambridge: Cambridge University Press.

Guest, I. (1990) Behind the Disappearances: Argentina's Dirty War Against Human Rights Philadelphia: University Of Pennsylvania Press.

Hansen, S. \& Flynn, D. (2015) 'This is Not a Banksy: Street Art as Aesthetic Protest' Continuum: Journal of Media and Cultural Studies, 29, 6, 898-912.

Harper, D. (1987) Working Knowledge: Skill and Community in a Small Shop Chicago: Chicago University Press.

Hewson, D. (2007) The Seventh Sacrament London: Pan.

Hodges, D. (1977) The Legacy of Che Guevara: A Documentary Study London: Thames and Hudson.

Jay, M. (1993) Downcast Eyes: the Denigration of Vision in Twentieth-Century French Thought Berkeley: University of California Press.

Kaplan, D. and Li, W. [eds] (2006) Landscapes of the Ethnic Economy Lanham: Rowman \& Littlefield.

Lafrance, A. (2016) 'Pompeii's Graffiti and the Ancient Origins of Social Media' The Atlantic Magazine, March $29^{\text {th }}$.

Lennon, J. (2014) 'Assembling a Revolution: Graffiti, Cairo and the Arab Spring' Cultural Studies Review, 20, 1, 237-75.

Levy, C. (1996) 'From Fascism to 'Post-Fascists': Italian Roads to Modernity' in R. Bessel [ed] Fascist Italy and Nazi Germany: Comparisons and Contrasts Cambridge: Cambridge University Press. 
Lewis, P. (2001) Guerrillas and Generals: The Dirty War in Argentina Westport: Greenwood Press.

Lewis, W. (2005) Louis Althusser and the Traditions of French Anarchism Lanham, MD: Lexington Books.

Lewisohn, C. (2008) Street Art: The Graffiti Revolution London: Tate Publishing.

Mammone, A. (2010) Italian neo-Fascism from 1943 to the Present Day London: Routledge.

Manco, T. (2002) Stencil Graffiti London: Thames \& Hudson.

Marchi, P. (2007) Italia Spray: Graffiti e Dintorni, 1967-2007 Siena: Protagon Editori.

Mariátegui, J. (1928) Seven Interpretive Essays on Peruvian Reality Austin: University of Texas Press [M.Uriquidi 1971 translation].

Margolis, E. \& Pauwels, L. (2011) The Sage Handbook of Visual Research Methods London: Sage.

Mathieson, E. (2007) Street Art and the War on Terror London: Rebellion Books.

Mead, M. \& Bateson, G. (1942) Balinese Character: A Photographic Analysis New York: New York Academy of Sciences.

Miklavcic, A. (2008) 'Slogans and Graffiti: Postmemory among Youth in the ItaloSlovenian Borderland' American Ethnologist, 35, 3, 440-453.

Milnor, K. (2014) Graffiti and the Literary Landscape in Roman Pompeii Oxford: Oxford University Press.

Mininno, A. (2008) Graffiti Writing: Origini, Significati, Tecniche Milano: Mondadori.

Moraes, X. and Rivas, M. [eds] (2008) Montepintado: Graffiti, Stencils y Stickers de Montevideo Montevideo: Trasluz.

Naar, J. (2007) The Birth of Graffiti Munich: Prestel.

Nwoye, O. (1993) 'Social Issues on Walls: Graffiti in University Lavatories' Discourse and Society, 4, 4, $419-442$.

Palmer, R. (2008) Street Art Chile London: Eightbooks.

Pan, L. (2014) 'Who is Occupying Wall and Street: Graffiti and Urban Spatial Politics in Contemporary China' Continuum: Journal of Media and Cultural Studies 28, 1, 136-153.

Pavone, C. (1991) Una guerra civile Turin: Bollati-Boringhieri. 
Peiter, S. (2009) Guerilla Art London: Lawrence King Publishing

Penn, R. (2002) 'Football and Local Economic Development' Singer \& Friedlander Soccer Review, Leicester, pp 58-62. (also available at www.le.ac.uk/crss/)

Penn, R. (2004) 'Sport e Sviluppo Locale: I'Esperienza del calcio inglese' in U. Lago, A. Baroncelli and S. Szymanski [eds], II Business de Calcio: Successi Sportivi e Rovesci Finanziari.

Penn, R. (2005) 'Cathedrals of Sport: Football Stadia in Contemporary England' Soccer Review, 4, 2005, 27-30.

(also available ar http://www.supportersdirect.org/englandwales/library.htm)

Penn, R. (2006a) 'Sport e sviluppo economico locale: l'esperienza del calcio inglese' in Bortoletto, N. and Mazza, B, (eds) Tempi e Spazi dello Sport: Italia - Inghilterra Modelli a Confronto II Piccolo Libro : Teramo, Italy.

Penn, R. (2006b) 'Le Cattedrali dello Sport: gli stadi di calico nell' Inghilterra contemporanea' in Bortoletto, N. and Mazza, B. [eds], Tempi e Spazi dello Sport : Italia - Inghilterra medelli a confronto II Piccolo Libro : Teramo, Italy.

Penn, R. (2008) 'The English Football Stadium as a Site of Post-Modern Consumption: Text and Image' Sociologia del Lavoro, No. 108, 2008, 141-147.

Phillips, S. (1999) Wallbangin': Graffiti and Gangs in L.A. Chicago: University of Chicago Press.

Pink, S. (2012) [ed] Advances in Visual Methodology London: Sage.

Porro, N. (2008) Sociologia del Calcio Roma: Carocci.

Pozzoni, S. (2005) Dove sono gli Ultrà? Milano: Zelig.

Robson, M. (2006) Italy: The Rise of Fascism London: Hodder Murray.

Rocker, R. (1938) Anarcho-Syndicalism: Theory and Practice London: Secker \& Warburg.

Rose, G. (2007) [2 ${ }^{\text {nd }}$ Edition] Visual Methodologies: An Introduction to the Interpretation of Visual Materials London: Sage.

Ross, J. (2016) [ed] Routledge Handbook of Graffiti and Street Art London: Routledge.

Ross, J., Bengsten, P., Lennon, J., Phillips, S. and Wilson, J. (2017) 'In Search of Academic Legitimacy: The Current State of Scholarship on Graffiti and Street Art' The Social Science Journal, 54, 411-419. 
Roversi, A. (2006) L'Odio in Rete: siti ultras, nazifascismo online, jihad electronica Bologna: il Mulino. [available in English as Hate on the Net: Extremist Sites, NeoFascism On-Line, Electronic Jihad Aldershot: Ashgate].

Ruiz, M. (2008) Graffiti Argentina London: Thames \& Hudson.

Sampson, R. (2102) Great American City: Chicago and the Enduring Neighborhood Effect Chicago: Chicago Unversity Press.

Sampson, R. and Raudenbasch, S. (1999) 'Systematic Social Observation of Public Spaces: a New Look at Disorder in Urban Neighborhoods', American Journal of Sociology, 105, 3,603-651.

Sampson, R. and Raudenbasch, S. (2004) 'Seeing Disorder: neighbourhood Stigma and the Social Construction of "Broken Windows"', Social Psychology Quarterly 67, 4, 319-342.

Snyder, G. (2009) Graffiti Lives: Beyond the Tag in New York's Urban Underground New York: New York University Press.

Tacchi, F. (2000) Storia Illustrata del Fascismo Firenze: Giunti.

Taylor, D. (1997) Disappearing Acts: Spectacles of Gender and Nationalism in Argentina's Dirty War Durham: Duke University Press.

Ten Have, P. (2004) Understanding Qualitative Research and Ethnomethodology London: Sage.

Testa, A. \& Armstrong, G. (2012) Football, Fascism and Fandom: The UltraS of Italian Football London: A \& C Black.

Valle, I. \& Weiss, E. (2010) 'Participation in the Figured World of Graffiti' Teaching and Teacher Education, 26, 128-135.

Vanderveen, G. \& van Eijk, G. (2016) 'Critical but Beautiful: A Study on Graffiti and the Role of Value Judgments and Context on Perceiving Disorder' European Journal on Criminal Policy and Research, 22, 107-125.

Williamson, G. (2004) The Waffen-SS (3): 11 - 23. Divisions Oxford: Osprey.

Wilson R. (1986) The Illuminati Papers Berkeley: Ronin Press. 